\title{
Interannual variation in phytoplankton blooms and zooplankton productivity and abundance in the Gulf of Maine during winter
}

\author{
Edward G. Durbin ${ }^{1, *}{ }^{,}$, Robert G. Campbell ${ }^{1}$, Maria C. Casas ${ }^{1}$, Mark D. Ohman ${ }^{2}$, \\ Barbara Niehoff $^{3}$, Jeffrey Runge ${ }^{4}$, Melissa Wagner ${ }^{1}$ \\ ${ }^{1}$ Graduate School of Oceanography, University of Rhode Island, Narragansett, Rhode Island 02882-1197, USA \\ ${ }^{2}$ Integrative Oceanography Division, Scripps Institution of Oceanography, La Jolla, California 92093-0218, USA \\ ${ }^{3}$ Alfred Wegener Institute for Polar and Marine Research, Columbusstrasse, 27568 Bremerhaven, Germany \\ ${ }^{4}$ Ocean Process Analysis Laboratory, 142 Morse Hall, University of New Hampshire, Durham, New Hampshire 03824, USA
}

\begin{abstract}
An anomalous winter phytoplankton bloom was observed across the central Gulf of Maine during a winter cruise in late February 1999, but not during a similar mission to the same region in late February 2000. During the cruise in 1999, 0 to $40 \mathrm{~m}$ mean chl a concentrations were $>2 \mu \mathrm{g} \mathrm{l}^{-1}$, while in 2000 total chl a concentrations were $<1.0$, and $>5 \mu \mathrm{m}$ size fractions were $<0.5 \mu \mathrm{g}$ $\mathrm{l}^{-1}$. The presence of the bloom in 1999 could not be explained in terms of the critical depth hypothesis given conditions present at the time of the bloom. The large amount of colder, lower-salinity Scotian Shelf water present at the surface of the central Gulf of Maine in 1999 may have provided conditions suitable for the initiation of the bloom earlier during the winter. The presence of the winter bloom had a major effect on higher trophic levels. Zooplankton were $>10 \times$ more abundant in 1999 and included species typically not present in the central Gulf during winter. All developmental stages of planktonic copepods were present, including large numbers of older copepodid stages of species such as Calanus finmarchicus, indicating that the bloom had been proceeding for some time. RNA:DNA ratios of surface $C$. finmarchicus stage C5 and adult females were at or near maximum temperature-dependent values in 1999, but were considerably reduced in 2000. Egg production rates of C. finmarchicus were high in1999 but reduced in 2000. Both showed a curvilinear relationship with chl a. Analysis of gonads of females of other copepod species indicate similar between-year differences in reproductive rates. We suggest that the presence of the winter bloom in the central Gulf of Maine allows an extra generation of $C$. finmarchicus and other copepods to develop, leading to a buildup of the population during winter. This will have significant effects on downstream regions such as Georges Bank, which depend on re-supply from the Gulf of Maine.
\end{abstract}

KEY WORDS: Calanus finmarchicus · Gulf of Maine - Phytoplankton bloom · Egg production · RNA:DNA

\section{INTRODUCTION}

Phytoplankton production in the Gulf of Maine (GOM) typically follows the classic spring bloom cycle. It was in this region that Gran \& Braarud (1935) suggested that stabilization of the water column by thermal stratification allowed the phytoplankton to remain in the euphotic zone and grow. Further studies have shown that initiation of the winter-spring bloom in the GOM does not normally begin until late March-April (Bigelow 1926, Durbin et al. 1995, O'Reilly \& Zetlin 1998). Prior to the initiation of the bloom, phytoplankton levels are low with concentrations $<0.5 \mu \mathrm{g} \mathrm{l}^{-1}$ (Durbin et al. 1995, O'Reilly \& Zetlin 1998). The timing of the development of the bloom is considered to be controlled by light limitation (Gran \& Braarud 1935, Townsend \& Spinrad 1986). This is based on the concept of critical depth (Sverdrup 1953); the depth in the water column at which phytoplankton pho- 
tosynthesis, vertically integrated from the surface, equals respiration. The upper mixed layer must be less than the critical depth for a net increase in phytoplankton to occur. It is usually assumed that seasonal development of the thermocline, in combination with increasing solar radiation, is needed for the development of the bloom.

Timing of the development of the phytoplankton bloom may have important consequences for higher trophic levels. Studies indicate a generally low abundance of zooplankton in the GOM during winter (e.g. Bigelow 1926, Fish \& Johnson 1937, Sherman et al. 1983, Meise et al. 1990, Meise \& O'Reilly 1996, Jossi \& Kane 2000). The dominant copepod in the GOM during winter and spring, Calanus finmarchicus, returns to the surface after a resting period in early winter and begins reproduction (Durbin et al. 1997, Durbin et al. 2000). Based on studies in other regions and in the laboratory (Campbell et al. 2001a,b) we would expect growth and reproduction of $C$. finmarchicus to be limited by the low food concentrations normally present at this time prior to the spring bloom. In a modeling study of $C$. finmarchicus in the GOM, Lynch et al. (1998) found that they had to impose a food limitation effect to delay successful reproduction during the winter in order to fit available abundance data. Here we describe results from cruises across the GOM during late February 1999 and 2000. In 1999 it was clear that an extensive bloom

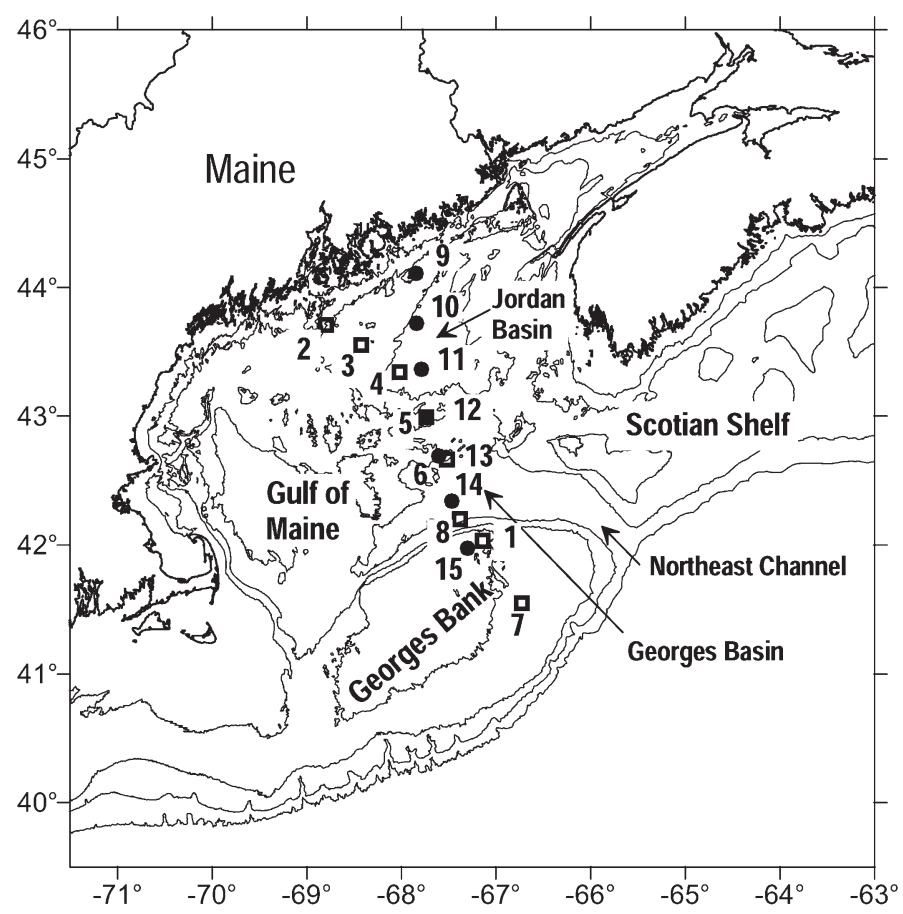

Fig. 1. Map of the Gulf of Maine (GOM) and Georges Bank (GB) showing station locations. Open squares are the stations sampled during February 1999, filled circles are the stations sampled during February 2000. Isobaths of 50, 100, 200, and $300 \mathrm{~m}$ are shown was occurring, whereas in 2000 phytoplankton concentrations were very low. Zooplankton were about a factor of 10 more abundant in 1999 than in 2000 and were growing and reproducing at, or near, maximal rates. By contrast during 2000 there was strong food limitation of growth and reproduction.

\section{MATERIALS AND METHODS}

Field sampling. Cruises were carried out between February 27 and March 4, 1999, on RV 'Endeavor' (Cruise EN319) and February 20 and 25, 2000, on NOAA ship 'Delaware II' along a N-S transect between the Maine Coast and Georges Bank (GB) (Fig. 1). At each station a CTD cast for vertical profiles of temperature and salinity was conducted. Water samples for analyses of nutrients and chl a were collected from a series of depths on the same casts using Niskin bottles mounted on a rosette sampler. Water samples for nutrients were filtered through $0.45 \mu \mathrm{m}$ Millipore cellulose acetate membrane filters, after first flushing the filter with water, and then frozen in $20 \mathrm{ml}$ polyethylene scintillation vials. Samples were analyzed for $\mathrm{NH}_{4}, \mathrm{NO}_{3}, \mathrm{NO}_{2}$, and $\mathrm{PO}_{4}$ using a Technicon II AutoAnalyzer and standard techniques (Whitledge et al. 1986). Size-fractionated chl a (total and $<5 \mu \mathrm{m}$ size fractions) was measured fluorometrically on discrete water samples (Parsons et al. 1984). Samples were filtered onto GF/F filters, immediately extracted in $90 \%$ acetone in a freezer for $24 \mathrm{~h}$, and then measured on a Turner fluorometer. The difference between the $<5 \mu \mathrm{m}$ and the total chl a gave the $>5 \mu \mathrm{m}$ size fraction.

Zooplankton was collected with a $1 \mathrm{~m}^{2}$ MOCNESS and a plankton pump at all stations. The MOCNESS was equipped with $0.150 \mathrm{~mm}$ nets. The MOCNESS zooplankton samples were collected from 0 to 15,15 to 40, 40 to 100, 100 to 200, and $200 \mathrm{~m}$ to the bottom. The plankton pump system, collected naupliar stages of copepods, as well as other small zooplankton. It consisted of a $6.4 \mathrm{~cm}$ diameter ribbed suction hose and an 8 hp diaphragm gasoline-powered pump which pumped water into a net $(0.035 \mathrm{~mm})$ suspended in a receiver tank on the deck of the ship. Flow rates (approx. $2001 \mathrm{~min}^{-1}$ ) and sample volumes were measured with a Signet flow meter. Samples were collected by deploying the hose to the maximum depth and then retrieving it at a constant rate while pumping continuously. Nets were switched at the appropriate intervals to provide integrated samples collected over 0 to 15,15 to 40,40 to 75 and 75 to $100 \mathrm{~m}$ depth ranges. Pump flow rates and hose volume were used to determine when the nets should be switched. Both MOCNESS and pump samples were preserved in $4 \%$ borate buffered formalin for later analysis. 
Egg production rates. Egg production (EP) rates of Calanus finmarchicus followed the procedure described in Runge \& Roff (2000). At each station 40 females from vertical live tows were sorted immediately after capture and placed individually in $30 \mathrm{ml}$ petri dishes. At $8 \mathrm{~h}$ intervals, eggs were counted and removed from the incubation dishes. Hatching success of $C$. finmarchicus eggs at Stns 3 to 8 was measured by incubation in 4 to 5 replicate scintillation vials for a 72 to $120 \mathrm{~h}$ period at 5 to $7^{\circ} \mathrm{C}$. Each scintillation vial contained 50 randomly selected eggs produced during incubations and gently sorted with an automatic pipet. Hatching success at Stn 1 (no measurements made at Stn 2) was estimated by removal of spawning females at the end of the $24 \mathrm{~h}$ incubation, maintaining eggs in the incubation dishes at 5 to $7^{\circ} \mathrm{C}$ and counting the number of nauplii present in each dish after $120 \mathrm{~h}$.

EP rates of Pseudocalanus spp. were estimated from observations of the rate of extrusion of eggs into egg sacs. Females were kept in groups of 5 in replicate scintillation vials $(45 \mathrm{ml})$ containing either filtered seawater or a feeding mixture of a diatom, Skeletonema costatum, and a green alga, Nannochloropsis spp. During sorting, the proportion of females carrying egg sacs was recorded. Only replicate vials in which all females were not carrying egg sacs at the time of initial sorting were analyzed. After $24 \mathrm{~h}$, the contents in the vials were preserved in $4 \%$ formalin for later analysis of egg sac number and body size. The daily 'egg extrusion rate' per female was calculated as the total number of eggs (either free or in attached or detached eggs sacs) divided by the number of females. To obtain the female-specific egg extrusion rates in the population, this rate was multiplied by 1 - (proportion of females carrying egg sacs initially), under the assumption that females already carrying egg sacs at the start of the incubation would not extrude another batch of eggs during the $24 \mathrm{~h}$ incubation.

Gonadal indices. Portions of the cod-end contents of the live net tows were preserved in formalin and glutaraldehyde for determination of the reproductive index and staging of gonad development. The reproductive index of Calanus finmarchicus females was estimated according to criteria described by Niehoff \& Hirche (1996) with modifications for changes in clutch number as described by Niehoff \& Runge (unpubl.). Stages of gonad development in Pseudocalanus spp. were assessed according to criteria described in Niehoff (2003).

RNA:DNA. Copepodid stage 5 (C5) and adult female (C6F) Calanus finmarchicus for nucleic acid measurements were usually sorted from the MOCNESS hauls. In 1999, copepods were always collected from the surface $(0$ to $15 \mathrm{~m})$ and bottom (depths varied) nets. In 2000, if the bottom depth exceeded 200 m, copepods were sorted from the 100 to $200 \mathrm{~m}$ net rather than the bottom net, which often did not collect enough individuals of both stages. In 1999 stages C5 and adult were also collected from a vertical haul $\left(1 \mathrm{~m}^{2}\right.$ ring net, 0.333 $\mathrm{mm}$ mesh, 0 to $40 \mathrm{~m}$ ) at Stn 1 on GB $4 \mathrm{~d}$ before the beginning of the transect at Stn 2. In 1999, naupliar stages were sorted from shallow vertical hauls $\left(1 \mathrm{~m}^{2}\right.$ ring net, $0.10 \mathrm{~mm}$ mesh) at Stn $2(0$ to $20 \mathrm{~m})$ and Stn 4 $(0$ to $50 \mathrm{~m})$ in the GOM. No naupliar stages were sampled for nucleic acid measurements in 2000.

The zooplankton was sorted immediately for nucleic acid sampling, and was kept as cold as possible during all subsequent steps. Zooplankton collected with the MOCNESS was kept cold by placing frozen gel ice packs into the buckets. Zooplankton collected with ring nets were diluted in filtered seawater and stored in $4 \mathrm{l}$ jars in a cooler on deck. Before sorting, zooplankton was concentrated, rinsed into a beaker with anesthetic solution (MS-222 in filtered seawater, $0.58 \mathrm{~g} \mathrm{l}^{-1}$ ) and kept on ice for not more than $1 \mathrm{~h}$. Small amounts of the anesthetized plankton were poured into $20 \times 60 \mathrm{~mm}$ petri dishes for sorting under the dissecting microscope. Zooplankton under the microscope was not chilled but was sorted quickly and replaced frequently. The target sample size was 25 stage $\mathrm{C} 5$ and C6F Calanus finmarchicus which were sampled individually. In cases where C. finmarchicus were scarce, as few as 5 individuals were sampled. We collected fewer than 10 individuals from only 2 of 50 samples. In 2000, stage C5 was virtually absent from the surface in the GOM and was only sampled at 1 station. Copepods were sorted by stage into depression slides containing a drop of anesthetic solution, and video images of each copepod were recorded so that prosome lengths could be measured later in the laboratory. After recording, the copepods were placed in $1.7 \mathrm{ml}$ screw-cap microcentrifuge tubes (Eppendorf Safe-Twist) and stored in the vapor phase of liquid nitrogen for the duration of the cruise. Upon return to the laboratory the samples were stored at $-80^{\circ} \mathrm{C}$.

Nucleic acids were measured by using the microplate fluorescent assay (MFA) described by Wagner et al. (1998). Copepod samples were homogenized in a $1 \%$ sarcosyl solution (N-lauroylsarcosine, a detergent) and RNA and DNA were quantified by measuring the fluorescence of the unpurified homogenate in ethidium bromide before and after treatment with ribonuclease A (RNase). RNA:DNA ratios were expressed relative to the laboratory-derived expected values for each stage under excess-food conditions (relative RNA:DNA index, Wagner et al. 2001).

Critical depth model. The critical depth hypothesis proposes that a spring phytoplankton bloom will occur once the critical depth, i.e. the depth at which total water column phytoplankton photosynthesis equals respiration, exceeds the depth of the upper mixed 
layer. A vertically integrated mean irradiance value of $20.9 \mathrm{~W} \mathrm{~m}^{-2}$ has been found to define this critical depth (Riley 1957, Pingree et al. 1976, Hitchcock \& Smayda 1977, Townsend \& Spinrad 1986, Townsend et al. 1992). The light reaching a particular depth $I_{z}$ is given by:

$$
I_{z}=I_{\mathrm{o}}(1-r) \exp \left(-\mathrm{k}_{1} z\left[1-\mathrm{k}_{2} \tan ^{-1}\left(\mathrm{k}_{3} z\right)\right]\right.
$$

(Townsend et al. 1992), where $I_{\mathrm{o}}$ is the solar radiation reaching the sea surface $\left(\mathrm{W} \mathrm{m}^{-2}\right), r$ is the reflectance at the air-sea boundary $(r \approx 0.021$ averaged over the visible spectrum), $z$ is the depth $(\mathrm{m})$, and the coefficients $\mathrm{k}_{1}, \mathrm{k}_{2}$ and $\mathrm{k}_{3}$ are attenuation coefficients from measured irradiance profiles. For non-bloom conditions in the GOM these were $\mathrm{k}_{1}=0.089 \mathrm{~m}^{-1}, \mathrm{k}_{2}=0.381 \mathrm{~m}^{-1}, \mathrm{k}_{3}$ $=1.72 \mathrm{~m}^{-1}$ (Townsend et al. 1992). Daily averages of incoming solar radiation for January and February 1999 and 2000 were taken from the Woods Hole weather station (http://www.whoi.edu/climate/). $I_{z}$ was then calculated at $1 \mathrm{~m}$ intervals between the surface and $50 \mathrm{~m}$ each day and the critical depth identified as the depth at which the depth-averaged vertically integrated irradiance was equal to $20.9 \mathrm{~W} \mathrm{~m}^{-2}$.

Zooplankton enumeration. Pump and MOCNESS samples were split with a folsum splitter into aliquots containing about 1200 animals. Both the nauplii and copepodids of Calanus finmarchicus and Pseudocalanus spp. were staged and enumerated. Adults of other taxa were identified to species in most cases. In several cases where taxa are very similar they were not distinguished. For example, adults of Oithona similis and O. colcarva were grouped together as Oithona spp., although most were $O$. similis. Younger stages were grouped as copepodids and nauplii and identified to species where possible (e.g. Temora longicornis), or to genus where it was not possible to identify the younger stages to individual species (e.g. Centropages hamatus, C. typicus and C. bradyi). Other zooplankton taxa were identified to the lowest possible taxon and enumerated. Data were entered into an Oracle $^{\circledR}$ database that can be queried on the web at http://globec.gso.uri.edu.

For analysis of depth-distribution the weighted mean depth (WMD) was calculated from:

$$
\mathrm{WMD}=\sum\left(n_{\mathrm{i}} z_{\mathrm{i}}\right) / \sum n_{\mathrm{i}}
$$

where $n_{\mathrm{i}}$ is the number of animals within each depth interval $\left(\mathrm{m}^{-2}\right)$ and $z_{\mathrm{i}}$ is the depth of the middle of the depth interval (Roe et al. 1984).

Zooplankton taxonomic analysis. For descriptive analysis of the taxonomic abundance, data from the MOCNESS and pump were combined. All nauplii data were from the pump samples. Pump data for other taxa were compared with MOCNESS data from the upper $100 \mathrm{~m}$ (Wilcoxon's signed rank test). Taxa significantly more abundant in the pump samples $(p<0.05)$ in- cluded Microcalanus spp. copepodids, Microsetella norvegica copepodids and adults, Oithona spp. copepodids, and Oncaea spp. copepodids and adults. Pump data for these taxa were used in the analysis. For Pseudocalanus spp. copepodids there were no significant differences between pump and MOCNESS for any stage (partly because of the small sample size). However abundance was greater in the pump samples and we used these for analysis.

Mortality. Estimates of mortality rates were made for successive stage pairs of Calanus finmarchicus nauplii from N2 through N6 using the vertical life table (VLT) method (Aksnes \& Ohman 1996, Ohman et al. 2002). Mortality estimates exclude N1 because of a sampling bias by the pump (Ohman et al. 2002) and extend only through the N5/N6 stage pair because early copepodids were too rare for reliable estimates of stage ratios. Mortality rates for a combined egg-through-N2 stage were made using a modified version of the VLT method that incorporates estimates of daily EP into the water column by $C$. finmarchicus (see Ohman et al. 2002). Stage durations for egg through N2 were estimated from the temperature-dependent Belehradek relations in Campbell et al. (2001b). Stage durations for feeding naupliar stages (N3 through N6) were based on multiples of the Belehradek functions in Campbell et al. (2001b). The multipliers were based on RNA:DNA ratios of $C$. finmarchicus in the 2 winter cruises, which suggested that stage durations were slowed to 1.1 to 1.6 times Belehradek predictions in February 1999 and from 1.4 to 3.0 times Belehradek predictions in February 2000.

\section{RESULTS}

\section{Hydrography}

Adjacent to the Maine coast the water column was completely mixed to the bottom during both years (Fig. 2). On GB the water was well-mixed during February 2000 (Stn 15), whereas during February 1999 (Stn 7) there was a shallow layer of colder, less salty water at the surface and a well-mixed water column extending to the bottom beneath this. Surface waters over most of the central GOM were colder and less salty during 1999 compared with 2000 (Fig. 2), indicating the presence of Scotian Shelf water. During 2000 there was a plume of colder, lower-salinity Scotian Shelf water extending into the GOM over Georges Basin (Stn 14, Fig. 2). A large mass of warm slope water was present at depth in the central GOM with a very sharp pycnocline at around $80 \mathrm{~m}$. In 1999, the bottom water was colder, less salty, and the pycnocline less strong. In the cen- 

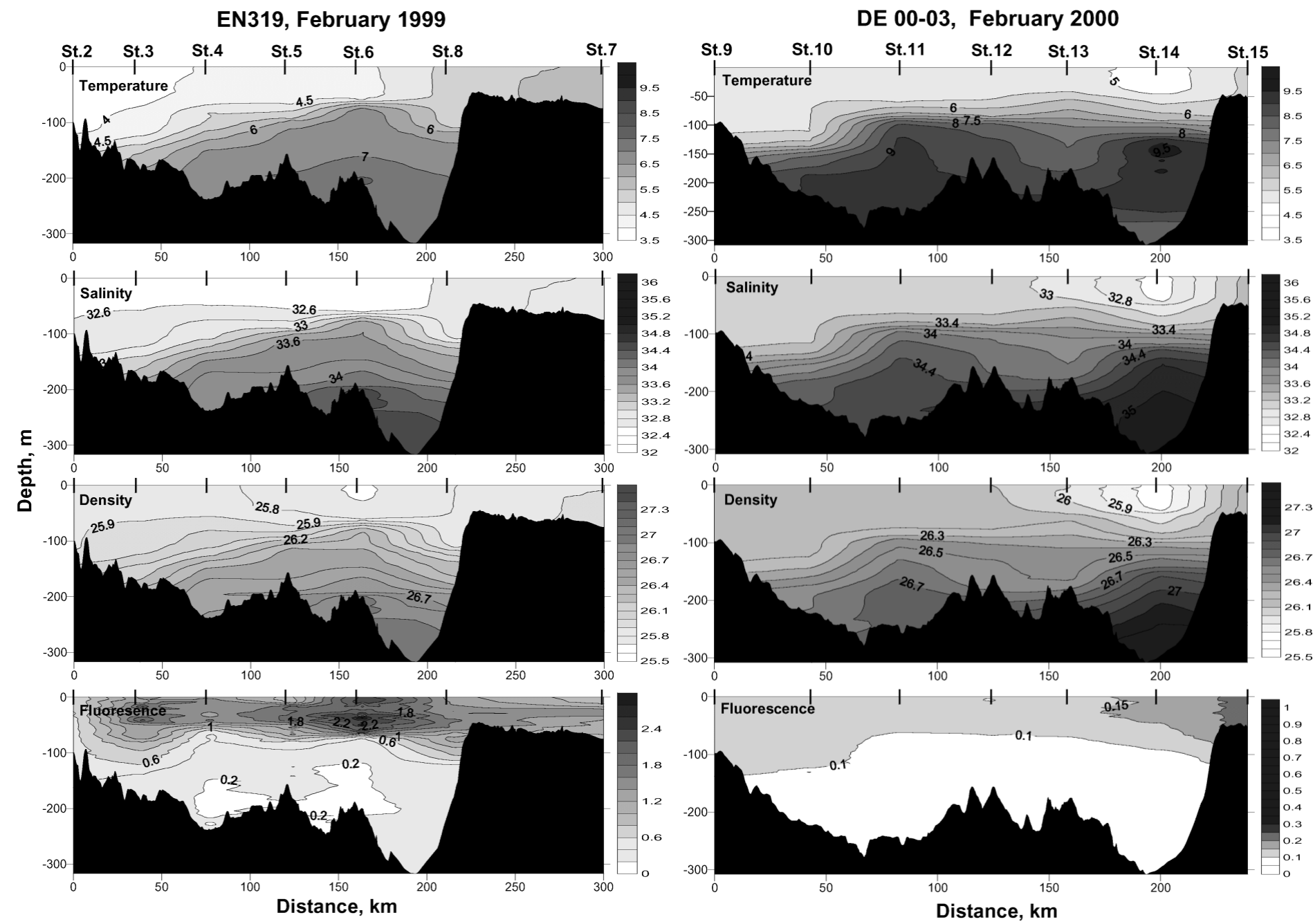

Fig. 2. Vertical sections of temperature, salinity, density and fluorescence between the Maine Coast and Georges Bank during late February 1999 and 2000. Transect distance is the distance from the first station adjacent to the Maine coast

tral GOM the mixed layer shallowed during both years due to a doming of the pycnocline above the deep water (Fig. 2).

During 1999 the upper mixed-layer depths (the depth at which the difference in sigma-t from that at the surface was >0.04) in the central GOM were relatively shallow (between $43 \mathrm{~m}$, Stn 5 and $59 \mathrm{~m}$, Stn 6, Table 1). Adjacent to the Maine coast the mixed layer extended to the bottom (93 m, Stn 2) while adjacent to GB in Georges Basin it extended to $102 \mathrm{~m}$ (Stn 8). In 2000, the mixed layer adjacent to the Maine Coast extended to the bottom at Stn $9(73 \mathrm{~m})$, and to $125 \mathrm{~m}$ at Stn 10. In the central GOM during February 2000, (Stns 11 and 12) mixed-layer depths were 60 and $63 \mathrm{~m}$. In Georges Basin during this year there was no mixed layer at Stn 13 and a relatively shallow one at Stn 14 (43 m). These were in the frontal region (Stn 13), and inside, a plume of colder, less salty, Scotian Shelf water flowing into the GOM (Stn 14, Fig. 2).
Table 1. Mixed-layer depths in the Gulf of Maine during February 1999 and 2000 determined as the depth at which the difference in sigma- $t$ from that at the surface is $>0.04$. At Stn 2 in 1999 and Stn 9 in 2000 the mixed-layer depth extended to the bottom

\begin{tabular}{|ccc|}
\hline & Stn & Depth $(\mathrm{m})$ \\
\hline $\mathbf{1 9 9 9}$ & 2 & 93 (bottom) \\
& 3 & 73 \\
& 4 & 51 \\
& 5 & 43 \\
& 6 & 59 \\
& 8 & 102 \\
$\mathbf{2 0 0 0}$ & 7 & 12 \\
& 9 & 73 (bottom) \\
& 10 & 60 \\
& 11 & 63 \\
& 12 & 34 \\
& 13 & 43 \\
& 14 & 47 \\
\hline
\end{tabular}




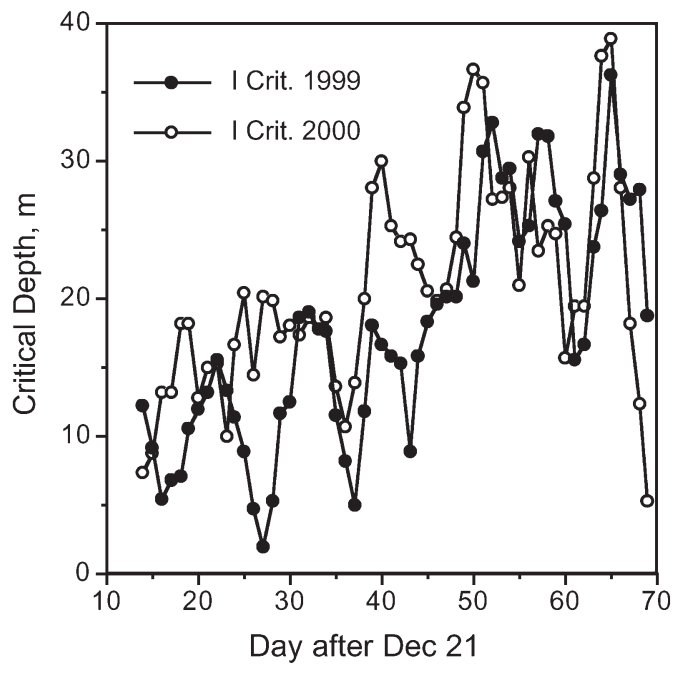

Fig. 3. Critical depths for the Gulf of Maine during January and February 1999 and 2000. Depths were calculated using pre-bloom extinction coefficients and incoming solar radiation measured at Woods Hole

\section{Critical depths}

Calculated winter-time critical depths in the GOM showed considerable short-term variation (Fig. 3). Means $( \pm$ SE) for January 1999 and 2000 were $11.5 \pm$ 1.6 and $16.6 \pm 1.9 \mathrm{~m}$, respectively, and $24.7 \pm 2.6$ and $24.1 \pm 2.8 \mathrm{~m}$ for February. All critical depths were less than the mixed-layer depths observed during February of both years.

\section{Chl $a$ and nutrients}

Chl a concentrations (0 to $40 \mathrm{~m}$ mean) differed greatly between years (Fig. 4). During 1999 a phytoplankton bloom was occurring in the central GOM where chl a concentrations were $>3 \mu^{-1} \mathrm{l}^{-1}$ (Fig. 4). Concentrations were intermediate (1.71 and $1.9 \mathrm{\mu g} \mathrm{l}^{-1}$ respectively), in Georges Basin and on $\mathrm{GB}$, and were quite low $\left(0.58 \mathrm{\mu g} \mathrm{l}^{-1}\right)$ in the well-mixed water adjacent to the Maine coast. Large diatoms dominated the phytoplankton at all but the Maine coastal station and, as a result, most of the chl a was in the $>5 \mu \mathrm{m}$ size-fraction (Fig. 4). In the central GOM (Stns 5 and 6) highest levels of chl a were found near the base of the mixed layer at about $40 \mathrm{~m}$ (Fig. 2). In contrast, during February 2000, chl a concentrations were uniformly low across the GOM $\left(<0.5 \mathrm{gg} \mathrm{l}^{-1}\right)$, with most of the chl $a$ in the $<5 \mu \mathrm{m}$ size-fraction (Fig. 4). These were indicative of pre-bloom conditions. On GB, however, concentrations were higher $\left(2.01 \mathrm{\mu g} \mathrm{l}^{-1}\right)$, indicating that the spring bloom was already underway.
Surface ( 0 to $40 \mathrm{~m}$ ) nitrate concentrations during 1999 were highest in the well-mixed water adjacent to the Maine Coast $(11.0 \mu \mathrm{M})$, lowest in the central GOM (Stns 5 and 6, 7.0 and $6.25 \mu \mathrm{M}$, respectively), and then higher again at the deeply mixed Georges Basin (Stn 8) and on GB (Stn 7) (Fig. 4). During February 2000, surface nitrate values across the central GOM were higher than 1999 at all stations but Stn 15 in Georges Basin (Fig. 4), which was in the plume of lower-salinity Scotian Shelf water (Fig. 2). Concentrations increased again on GB (Fig. 4).

Plots of nitrate against salinity showed that during 1999 the deeper samples, and those at the well-mixed Maine coastal station (Stn 2), lay along a common mixing curve (Fig. 5). Surface mixed-layer samples at other stations had nitrate values that lay beneath this mixing curve. By contrast, during 2000, all data, including the surface mixed-layer stations, lay along the same mixing curve (Fig. 5). This indicates that phytoplankton uptake of nitrate in the surface mixed layer had been occurring during 1999, but not during 2000. There was a difference in elevation of the 2 mixing curves with that for

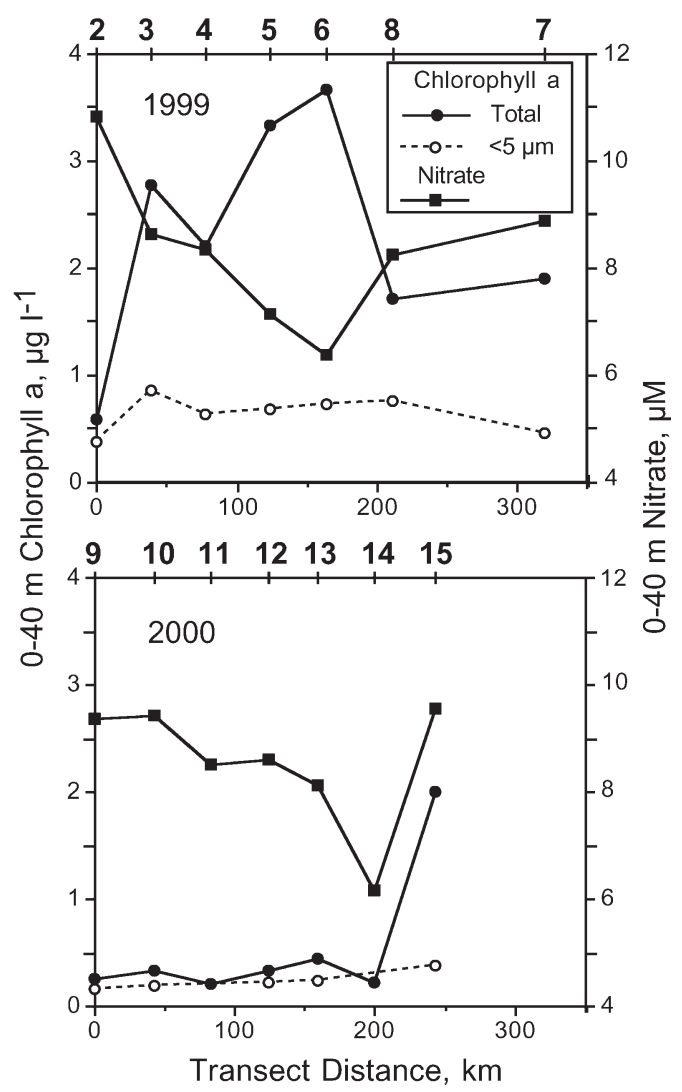

Fig. 4. Mean ( 0 to $40 \mathrm{~m}$ ) total and $<5 \mu \mathrm{m}$ chl a concentrations, and nitrate concentrations across the Gulf of Maine during late February 1999 and 2000. Transect distance is the distance from the first station adjacent to the Maine coast. Station numbers are shown at the top of each figure 


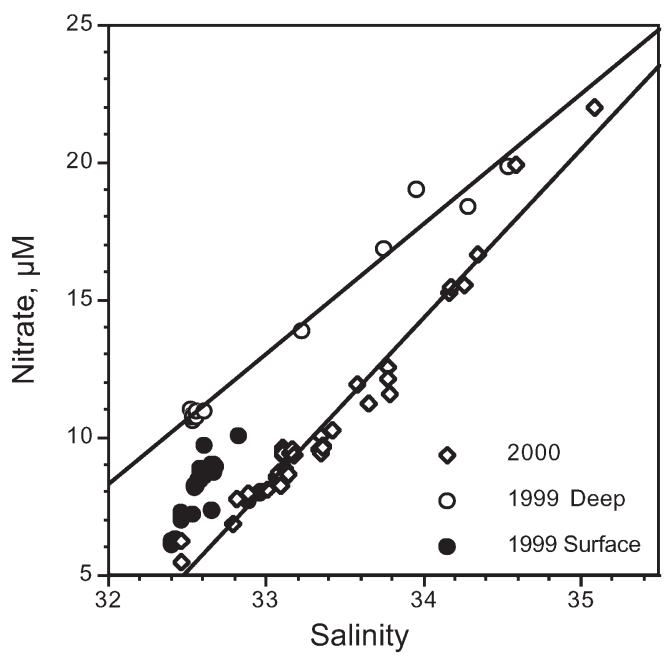

Fig. 5. Plots of nitrate vs salinity for Gulf of Maine stations during late February 1999 and 2000. Least squares linear regressions for the deeper 1999 data $\left(\mathrm{NO}_{3}=4.735[\mathrm{Sal}]-143.2\right)$, and all of the 2000 data $\left(\mathrm{NO}_{3}=6.108[\mathrm{Sal}]-193.3\right)$ are shown

1999 being about $3 \mu \mathrm{M}$ nitrate higher than that for 2000 (Fig. 5). This indicates that both the slope waters entering the GOM at the bottom, and surface waters from the Scotian Shelf, had higher nitrate concentrations during 1999 compared with 2000.

During 1999 there was a strong negative relation between mean 0 to $40 \mathrm{~m}$ nitrate and chl a (Fig. 6) with the highest nitrate concentrations occurring at the station with lowest chl a (Stn 2), and lowest nitrate at the highest chl a station (Stn 6). This indicates that the bloom had been occurring for sufficient time to have drawn down the water column nitrate. In contrast, during February 2000, there was no relationship between nitrate and chl a (Fig. 6). The GB station (Stn 15), which had the highest chl a levels (2.01 $\left.\mathrm{\mu g} \mathrm{l}^{-1}\right)$, was not depleted in nitrate compared with the GOM stations, which had very low chl $a$, suggesting that the bloom on GB had not been progressing long enough to draw down the nutrient levels. At Stn 14 in Georges Basin, both surface nitrate and chl a were quite low but still lay on the same nitrate-salinity mixing curve as the other stations (Fig. 5). This station was in the low-salinity plume indicating low nitrate concentrations in the surface water being advected into the GOM from the Scotian Shelf.

\section{Zooplankton abundance and vertical distribution in the GOM}

Copepods dominated the zooplankton in the GOM during February of both years (Tables $2 \& 3$ ). The water column total copepods (nauplii, copepodids and adults) at the 6 GOM stations were 87 and $98 \%$ of the total zooplankton during 1999 and 2000, respectively (Table 2). The dominant copepods were the calanoids Calanus finmarchicus, Pseudocalanus spp., Centropages spp. (primarily C. typicus), Metridia spp. (primarily M. lucens), Clausocalanus arcuicornis, Paracalanus parvus and Microcalanus pusillus, the cyclopoids Oithona spp. (primarily O. similis and O. spinirostris), the poecilistomatoid Oncaea spp., and the harpacticoid Microsetella norvegica. The dominant non-copepod zooplankton included the pteropod Limacina spp., and polychaetes and chaetognaths. Among the copepods the small cyclopoid Oithona spp. was most abundant during both years with water column totals of $1070000 \mathrm{~m}^{-2}$ during 1999 and $131000 \mathrm{~m}^{-2}$ in 2000 (Tables 2 \& 3). However, the biomass was dominated by the very large numbers of Metridia spp. adults present during $1999\left(11400 \mathrm{~m}^{-2}\right)$, and C. finmarchicus adult females during $2000\left(3700 \mathrm{~m}^{-2}\right)$.

While the general taxonomic composition of the zooplankton was similar between years, the abundance of zooplankton in the GOM was much greater during February 1999 than during 2000 (Tables 2 \& 3). Median water column total nauplii, copepodids and adults of all copepod taxa combined were 882000 , 514000 and $138000 \mathrm{~m}^{-2}$ during 1999, and 149000 , 29000 and $7660 \mathrm{~m}^{-2}$ during 2000. Most taxa were significantly more abundant in 1999 than during 2000 (Wilcoxon 2-sample test, p < 0.05, Tables $2 \& 3$ ). These included median total Centropages spp., Metridia spp., Oithona spp., and Pseudocalanus spp. (nauplii, copepodids and adults), which were about 10-fold more abundant during 1999 compared with 2000 (Table 4). Other taxa much more abundant in 1999 included adult Clausocalanus arcuicornus and Para-

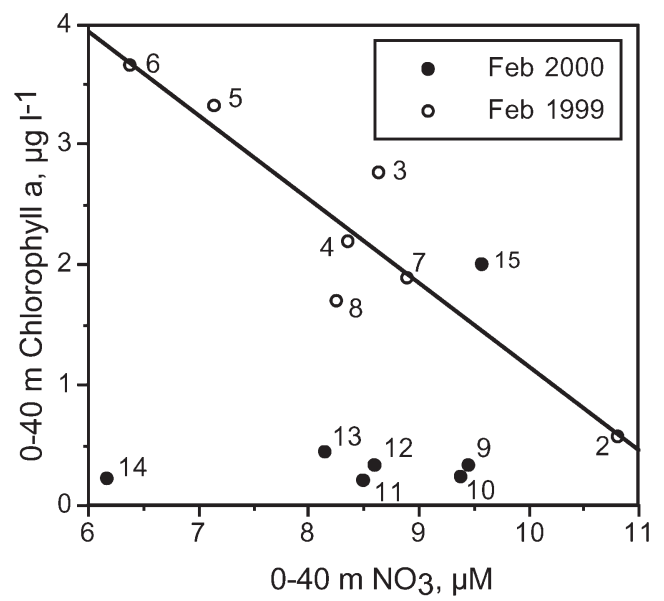

Fig. 6. Plot of mean 0 to $40 \mathrm{~m}$ nitrate against chl a. Station numbers are indicated next to data point. A linear regression is shown for the 1999 nitrate against chl a data $\left(\mathrm{NO}_{3}=-1.24[\mathrm{Chl}]+11.21, \mathrm{r}^{2}=0.86\right)$ 
Table 2. Zooplankton abundance in the Gulf of Maine (GOM) and on Georges Bank (GB) (no. $\mathrm{m}^{-2}$ ) during February 1999. Differences between 1999 and 2000 for GOM stations were tested for significance (Wilcoxon 2-sample test). Levels of significance are indicated $\left({ }^{*} \mathrm{p}<0.05,{ }^{* *} \mathrm{p}<0.01\right)$ along with whether 1999 samples are $>$ or $<2000 . \mathrm{N}=$ nauplii, $\mathrm{C}=$ copepodid, $\mathrm{A}=$ adult, ns $=$ not significant

\begin{tabular}{|c|c|c|c|c|c|c|c|c|}
\hline & Stn 2 & Stn 3 & Stn 4 & Stn 5 & Stn 6 & Stn 8 & Stn 7 & Significant \\
\hline Calanus finmarchicus, $\mathrm{N}$ & 23600 & 32200 & 26900 & 53700 & 43500 & 8690 & 76100 & ns \\
\hline Calanus finmarchicus, $\mathrm{C}$ & 4530 & 6210 & 22000 & 21300 & 18000 & 5520 & 8840 & ${ }^{* *},>$ \\
\hline Calanus finmarchicus, A & 1410 & 831 & 1540 & 1520 & 1340 & 1610 & 514 & ${ }^{* *},<$ \\
\hline Centropages spp., N & 2070 & 8480 & 5070 & 20000 & 22100 & 46400 & 28300 & ${ }^{*},>$ \\
\hline Centropages spp., C & 3640 & 6390 & 6950 & 6000 & 4490 & 11000 & 5850 & ${ }^{* *},>$ \\
\hline Centropages typicus, A & 1030 & 2290 & 2970 & 2160 & 3070 & 2280 & 552 & ${ }^{* *},>$ \\
\hline Clauso./Paracalanus, $\mathrm{N}$ & 9670 & 6250 & 31200 & 24700 & 64900 & 4900 & 59200 & ns. \\
\hline Clauso./Paracalanus, C & 246 & 2990 & 2020 & 1040 & 2340 & 896 & 9280 & ns. \\
\hline Clausocalanus arcuicornis, A & 242 & 642 & 473 & 580 & 660 & 208 & 0 & ${ }^{* *},>$ \\
\hline Euchaeta spp., C & 0 & 103 & 680 & 0 & 83 & 113 & 0 & ns. \\
\hline Euchaeta spp., A & 0 & 0 & 53 & 0 & 58 & 35 & 0 & ns. \\
\hline Metridia spp., $\mathrm{N}$ & 19000 & 80100 & 154000 & 221000 & 242000 & 42300 & 172000 & ${ }^{* *},>$ \\
\hline Metridia spp., C & 2710 & 16500 & 17400 & 16200 & 16100 & 33100 & 6880 & ${ }^{* *},>$ \\
\hline Metridia longa, A & 102 & 618 & 898 & 101 & 272 & 98 & 67 & ${ }^{* *},>$ \\
\hline Metridia lucens, A & 3040 & 34200 & 14200 & 8580 & 6550 & 33200 & 982 & ${ }^{* *},>$ \\
\hline Microcalanus spp., C & 1770 & 0 & 4360 & 6960 & 10800 & 967 & 8130 & ${ }^{*},>$ \\
\hline Microcalanus pusillus, A & 1290 & 7850 & 6660 & 4300 & 2940 & 8990 & 1130 & ${ }^{* *},>$ \\
\hline Microsetella norvegica, $\mathrm{N}$ & 281 & 6750 & 8100 & 11000 & 7170 & 20900 & 8800 & ns. \\
\hline Microsetella norvegica, C \& A & 92100 & 289000 & 81900 & 53100 & 53100 & 99600 & 24200 & ${ }^{* *},>$ \\
\hline Oithona spp., N & 173000 & 1040000 & 494000 & 698000 & 555000 & 615000 & 334000 & ${ }^{* *},>$ \\
\hline Oithona spp., C & 95700 & 507000 & 282000 & 445000 & 409000 & 350000 & 160000 & ${ }^{* *},>$ \\
\hline Oithona spp., A & 43200 & 112000 & 87700 & 123000 & 109000 & 101000 & 32400 & ${ }^{* *},>$ \\
\hline Oithona spinirostris, A & 458 & 2360 & 7980 & 6220 & 4850 & 24000 & 1300 & ${ }^{* *},>$ \\
\hline Oncaea spp., C \& A & 9600 & 4080 & 12500 & 4390 & 13300 & 717 & 8150 & ${ }^{* *},>$ \\
\hline Paracalanus parvus, A & 140 & 1060 & 913 & 588 & 661 & 712 & 753 & ${ }^{* *},>$ \\
\hline Pseudocalanus spp., N & 24000 & 81300 & 56000 & 90000 & 55700 & 10800 & 84700 & ${ }^{* *},>$ \\
\hline Pseudocalanus spp., C & 33400 & 9420 & 10000 & 17900 & 8420 & 3220 & 37200 & ${ }^{* *},>$ \\
\hline Pseudocalanus spp., A & 10200 & 5630 & 5130 & 5460 & 2260 & 2040 & 9810 & ${ }^{* *},>$ \\
\hline Chaetognaths & 8 & 225 & 70 & 0 & 50 & 235 & 712 & ${ }^{* *},<$ \\
\hline Limacina & 30100 & 291000 & 229000 & 365000 & 313000 & 189000 & 60700 & ${ }^{* *},>$ \\
\hline Hydroids (polyps) & 0 & 0 & 0 & 0 & 0 & 35 & 1130 & \\
\hline Polychaetes & 196 & 64 & 2670 & 544 & 884 & 804 & 1270 & ns \\
\hline
\end{tabular}

calanus parvus (526 to $0 \mathrm{~m}^{-2}$ and 687 to $0 \mathrm{~m}^{-2}$ ), and adult and copepodid Microcalanus pusillus and Microsetella norvegica (8900 to $1 \mathrm{~m}^{-2}$ and 94600 to $14900 \mathrm{~m}^{-2}$ ). Total C. finmarchicus nauplii were not significantly different between years while, in contrast, copepodids were significantly more abundant in 1999 $\left(12100\right.$ to $\left.1100 \mathrm{~m}^{-2}\right)$, and adults significantly more abundant in 2000 (1500 to $3700 \mathrm{~m}^{-2}$, Wilcoxon 2-sample test, $\mathrm{p}<0.01$, Tables $2 \& 3$ ). Limacina was very abundant during 1999 but almost absent in 2000 (260 000 and $1600 \mathrm{~m}^{-2}$ respectively).

There were spatial differences in abundance across the GOM. During 1999, the 5 central stations were quite similar (Stns 3, 4, 5, 6 and 8) while the inshore station (Stn 2) had lower numbers of several taxa (Oithona spp., Metridia spp., and Limacina) and higher numbers of Pseudocalanus spp., copepodids and adults
(Table 2). During 2000 a number of taxa were considerably higher at Stn 14, which was in the plume of Scotian Shelf water, than elsewhere in the GOM. These included all stages of Metridia spp., Microsetella spp., and Oithona spp., and nauplii and copepodids of Clauso/Paracalanus and Pseudocalanus spp. (Table 3).

The age structures of the dominant copepods present in the GOM provide some interesting insights. Nauplii of these taxa were present during both years indicating that reproduction was occurring (Table 4). However, during 2000 copepodids constituted a smaller proportion of the total population of each species than in 1999. For example, for Metridia spp. and Oithona spp., copepodids were 11 and $35 \%$ of the total of each taxa in 1999 and only 4.3 and $11.4 \%$ during 2000 . The more detailed age 
Table 3. Zooplankton abundance in the Gulf of Maine (GOM) and on Georges Bank (GB) (no. $\mathrm{m}^{-2}$ ) during February 2000. See Table 2 for significance of differences between 1999 and 2000 GOM stations

\begin{tabular}{|c|c|c|c|c|c|c|c|}
\hline & Stn 9 & Stn 10 & Stn 11 & Stn 12 & Stn 13 & Stn 14 & Stn 15 \\
\hline Calanus finmarchicus, $\mathrm{N}$ & 4660 & 22800 & 14500 & 22000 & 11100 & 42300 & 85600 \\
\hline Calanus finmarchicus, C & 558 & 556 & 3110 & 1440 & 774 & 2550 & 4050 \\
\hline Calanus finmarchicus, A & 1710 & 3720 & 6140 & 3770 & 1860 & 4350 & 1560 \\
\hline Centropages spp., N & 1410 & 2920 & 1090 & 1160 & 1100 & 14200 & 22500 \\
\hline Centropages spp., C & 669 & 363 & 294 & 807 & 45 & 5290 & 4110 \\
\hline Centropages typicus, A & 106 & 59 & 2 & 117 & 31 & 79 & 81 \\
\hline Clauso./Paracalanus, $\mathrm{N}$ & 4240 & 5630 & 5930 & 16200 & 6260 & 45900 & 17400 \\
\hline Clauso./Paracalanus, C & 59 & 449 & 454 & 399 & 362 & 6120 & 2130 \\
\hline Clausocalanus arcuicornis, A & 0 & 0 & 0 & 0 & 45 & 0 & 0 \\
\hline Euchaeta spp., C & 10 & 58 & 369 & 3 & 34 & 214 & 20 \\
\hline Euchaeta spp., A & 24 & 218 & 2400 & 18 & 7 & 327 & 0 \\
\hline Metridia spp., $\mathrm{N}$ & 1430 & 3410 & 7200 & 7130 & 9470 & 39700 & 24900 \\
\hline Metridia spp., C & 259 & 299 & 508 & 416 & 62 & 1560 & 986 \\
\hline Metridia longa, A & 0 & 0 & 0 & 0 & 33 & 13 & 0 \\
\hline Metridia lucens, A & 309 & 725 & 744 & 1201 & 605 & 3350 & 513 \\
\hline Microcalanus spp., C & 416 & 25 & 300 & 674 & 16 & 0 & \\
\hline Microcalanus pusillus, A & 0 & 0 & 0 & 2 & 193 & 50 & 0 \\
\hline Microsetella norvegica, $\mathrm{N}$ & 194 & 1180 & 1970 & 4040 & 4670 & 15900 & 2460 \\
\hline Microsetella norvegica, C \& A & 9530 & 11800 & 7390 & 12100 & 17000 & 27300 & 5810 \\
\hline Oithona spp., N & 47700 & 99800 & 74800 & 143000 & 128000 & 430000 & 174000 \\
\hline Oithona spp., C & 41000 & 13800 & 6810 & 16160 & 9090 & 73200 & 53600 \\
\hline Oithona spp., A & 728 & 2390 & 1600 & 2050 & 2670 & 7030 & 3190 \\
\hline Oithona spinirostris, A & 57 & 146 & 180 & 368 & 1270 & 1660 & 65 \\
\hline Oncaea spp., C \& A & 1060 & 81 & 21 & 44 & 158 & 489 & 3670 \\
\hline Paracalanus parvus, A & 4 & 0 & 0 & 64 & 36 & 83 & 16 \\
\hline Pseudocalanus spp., N & 994 & 1330 & 720 & 220 & 336 & 18800 & 5930 \\
\hline Pseudocalanus spp., C & 172 & 116 & 128 & 35 & 21 & 1370 & 1120 \\
\hline Pseudocalanus spp., A & 145 & 307 & 105 & 135 & 44 & 97 & 402 \\
\hline Chaetognaths & 79 & 54 & 226 & 252 & 219 & 455 & 83 \\
\hline Limacina & 296 & 3630 & 560 & 2680 & 148 & 9920 & 227 \\
\hline Hydroids (polyps) & 0 & 0 & 0 & 0 & 0 & 0 & 1260 \\
\hline Polychaetes & 41 & 361 & 3760 & 508 & 1010 & 2300 & 262 \\
\hline
\end{tabular}

structure information available for Calanus finmarchicus and Pseudocalanus spp. illustrates this pattern more clearly (Fig. 7). During 1999 all stages of both taxa were present, and there was only a small decline in abundance with increasing stage. The age structures during 1999 suggest that stages C4 and C5 of both species were part of a recent cohort rather than remnants of a resting or nonactively growing population. By contrast, during 2000 the age structures of $C$. finmarchicus were quite different from the pattern observed in 1999. While there were actually more N1-3 present in the GOM during 2000 (median $17000 \mathrm{~m}^{-2}$ ), compared with 1999 (median $14100 \mathrm{~m}^{-2}$ ), there was a precipitous decline in abundance of the older stages of nauplii with a median abundance of N4-6 during 2000 of only $711 \mathrm{~m}^{-2}$ compared with $15600 \mathrm{~m}^{-2}$ during 1999 . Young copepodids (C1-4) were similarly very low in abundance during 2000 (median $243 \mathrm{~m}^{-2}$ ) compared with 1999 (median $8150 \mathrm{~m}^{-2}$ ) and constituted only $4.8 \%$ of the total C. finmarchicus population compared with $28 \%$ in 1999 (Table 4). Pseudocalanus spp. did not show a strong difference in age structure between years but overall abundance was much lower in 2000 (Fig. 7).

\section{Zooplankton abundance on GB}

Most taxa present in the GOM were also present at the GB station (Tables $2 \& 3$ ). Major differences during both years were the presence of the hydroid Clytia glacilis on GB and its absence in the GOM, larger numbers of Calanus finmarchicus nauplii, and fewer adult Metridia spp. on GB compared with the GOM. During 2000 there were also larger numbers of Pseudocalanus spp. on GB compared with the central GOM stations. 
Table 4. Median abundance (no. $\mathrm{m}^{-2}$ ) and age structures (\%) of the dominant copepods in the Gulf of Maine (GOM) during February 1999 and 2000. $\mathrm{N}=$ nauplii, $\mathrm{C}=$ copepodid, $\mathrm{A}=$ adult

\begin{tabular}{|c|c|c|c|c|}
\hline & \multicolumn{2}{|c|}{$1999-$} & \multicolumn{2}{|c|}{2000} \\
\hline & GOM Median & $\%$ & GOM Median & $\%$ \\
\hline Calanus finmarchicus, $\mathrm{N}$ & 29500 & 68 & 18300 & 79 \\
\hline Calanus finmarchicus, C & 12100 & 28 & 1110 & 5 \\
\hline Calanus finmarchicus, A & 1460 & 3 & 3750 & 16 \\
\hline Calanus finmarchicus, Total & 43060 & 100 & 23160 & 100 \\
\hline Centropages spp., N & 14200 & 63 & 1280 & 68 \\
\hline Centropages spp., C & 6190 & 27 & 516 & 27 \\
\hline Centropages spp., A & 2290 & 10 & 100 & 5 \\
\hline Centropages spp., Total & 22680 & 100 & 1900 & 100 \\
\hline Clauso./Paracalanus, $\mathrm{N}$ & 17200 & 86 & 6090 & 93 \\
\hline Clauso./Paracalanus, C & 1530 & 8 & 424 & 6 \\
\hline Clauso./Paracalanus, A & 1240 & 6 & 34 & 1 \\
\hline Clauso./Paracalanus, Total & 19970 & 100 & 6550 & 100 \\
\hline Metridia spp., $\mathrm{N}$ & 117000 & 81 & 7160 & 87 \\
\hline Metridia spp., C & 16400 & 11 & 358 & 4 \\
\hline Metridia spp., A & 11900 & 8 & 734 & 9 \\
\hline Metridia spp., Total & 145300 & 100 & 8250 & 100 \\
\hline Oithona spp., N & 585000 & 54 & 114000 & 87 \\
\hline Oithona spp., C & 379000 & 35 & 15000 & 11 \\
\hline Oithona spp., A & 114000 & 11 & 2480 & 2 \\
\hline Oithona spp., Total & 1078000 & 100 & 131480 & 100 \\
\hline Pseudocalanus spp., N & 55800 & 79 & 857 & 78 \\
\hline Pseudocalanus spp., C & 9720 & 14 & 122 & 11 \\
\hline Pseudocalanus spp., A & 5290 & 7 & 120 & 11 \\
\hline Pseudocalanus spp., Total & 70810 & 100 & 1100 & 100 \\
\hline Total nauplii & 818700 & & 148000 & \\
\hline Total copepodids & 424940 & & 17500 & \\
\hline Total adults & 136180 & & 7220 & \\
\hline
\end{tabular}

differences. However, different taxa occupied different depth ranges in the water column (Fig. 9, Table 5). During 1999 a number of taxa were close to the surface with WMD $<35 \mathrm{~m}$. These included Calanus finmarchicus nauplii, copepodids, and adult females, Centropages spp. nauplii and copepodids and $C$. typicus adult females and males, Pseudocalanus spp. copepodids and Limacina. A large group of taxa occupied a wider vertical range in the water column and were distributed throughout the mixed layer resulting in greater WMD values. These included Metridia spp. nauplii, Pseudocalanus spp. nauplii and adults, Oithona spp. nauplii, copepodids and adults, Clauscalanus/Paracalanus nauplii and copepodids, Clausocalanus arcuicornis females, and Microsetella spp. nauplii, copepodids and adults. A few taxa were deeper and near the bottom, or below, the mixed layer with WMD $>60 \mathrm{~m}$. These included Calanus finmarchicus males, Microcalanus pusillus males and females, Oithona spinirostris females, and Oncaea spp. copepodids and adults (Table 5).

During 2000, taxa sufficiently abundant for the estimation of WMD were significantly deeper in the water column than during 1999 (p $<$ 0.005, Wilcoxon 2-sample test,

\section{Vertical distribution of zooplankton taxa}

During February 1999, 3 of the GOM stations (Stns 2, 4 and 5) were occupied during the day, and the remainder at night. Metridia lucens and $M$. longa adult females and Metridia spp. copepodids were deeper during the day than at night ( $M$. lucens females WMD $116 \mathrm{~m}$ day, $38 \mathrm{~m}$ night; $M$. longa WMD $140 \mathrm{~m}$ day, $98 \mathrm{~m}$ night; Metridia spp. copepodids WMD $98 \mathrm{~m}$ day, $66 \mathrm{~m}$ night) and appeared to be undergoing diel vertical migration (DVM) (Fig. 8). During February 2000, only M. lucens females were sufficiently abundant for an analysis of DVM patterns. This species again appeared to be undergoing DVM and was deeper during the day (WMD $94 \mathrm{~m}$, Stns 11 and 12) than at night (WMD $57 \mathrm{~m}$, Stns 9, 10, 13 and 14).

For other taxa, the vertical distribution was similar across all of the GOM stations with no clear day-night
Table 5). The overall median WMD of all abundant taxa combined was $42 \mathrm{~m}$ in 1999, compared to $59 \mathrm{~m}$ in 2000. The WMD of Calanus finmarchicus copepodid stages was $116 \mathrm{~m}$ in 2000 and only $24 \mathrm{~m}$ in 1999. This large difference was due to the absence of younger actively growing stages in 2000, when most of the copepodid population were present as C5, which were at depth $(70 \%$ of the C5 were $>100 \mathrm{~m})$. In 1999, by contrast, large numbers of all stages were present and only a very small proportion of the $C$. finmarchicus C5 population $(20 \%)$ was at depth (>100 m). This suggests an actively growing population in 1999 and a resting population in 2000. Other groups showing large depth differences between years were $C$. finmarchicus males and naupliar stages, the life stages of Oithona spp. and Pseudocalanus spp., and the non-copepod taxa. C. finmarchicus females, however, remained close to the surface in both years. 

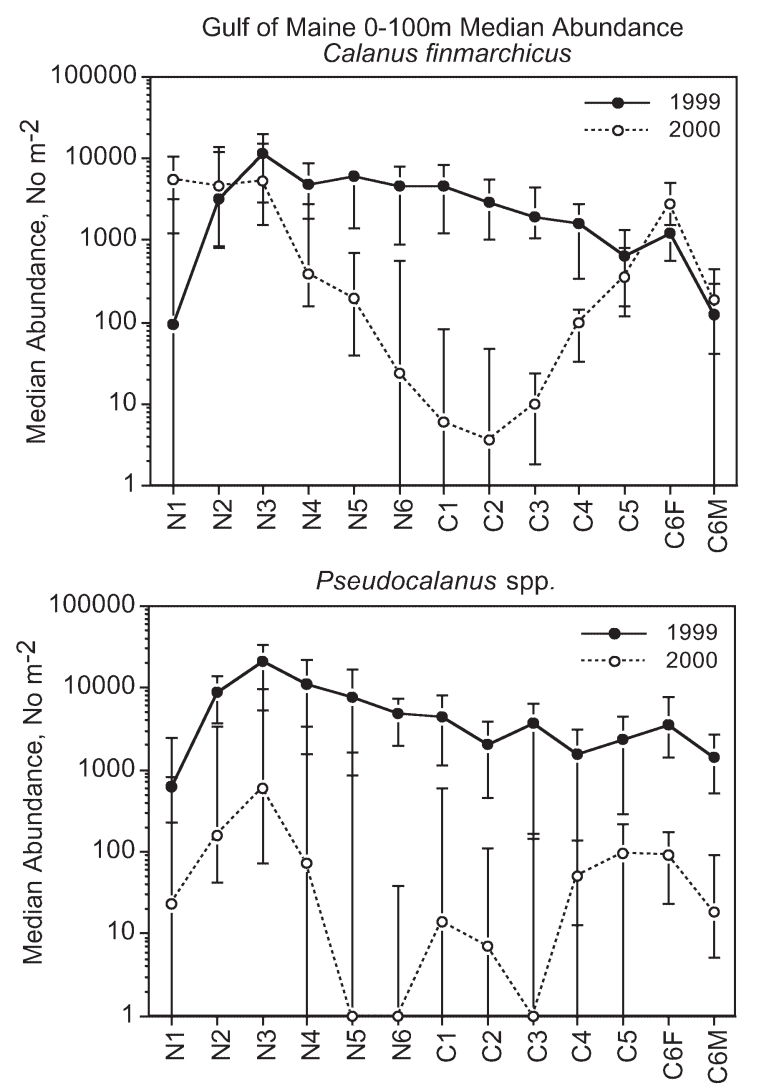

Fig. 7. Calanus finmarchicus and Pseudocalanus spp. Median 0 to $100 \mathrm{~m}$ abundance (no. $\mathrm{m}^{-2}$ ) of the different stages for Gulf of Maine stations sampled during February 1999 and 2000. For Calanus nauplii, data are from a plankton pump, while copepodite and adult data are from a $1 \mathrm{~m}^{-2}$ MOCNESS. For Pseudocalanus spp., all nauplii and copepodite data are from the plankton pump, while adult data are from the MOCNESS. $95 \%$ CI are shown

\section{Copepod nutritional and reproductive rates}

Relative RNA:DNA ratios of adult female Calanus finmarchicus were considerably higher at the surface than near bottom in the central GOM during both years (Fig. 10A,B), suggesting that the individuals at depth remained there in diapause and were not migrating to the surface to feed. RNA:DNA ratios were also low in deep-dwelling C5 in both years. In 1999, surface-dwelling C5 had higher RNA:DNA levels while in 2000, surface C5 had low RNA:DNA ratios and were not significantly different from deep C5 (although only 1 surface C5 station was sampled because of very low abundance at the others). In 1999, surface adult females had slightly higher relative RNA:DNA ratios than stage C5 copepodids (101 to 105 vs 83 to 95), with significant differences at Stns 2, 3 and 4 (1-way ANOVA, p < 0.05).

Relative RNA:DNA ratios of both stages at depth were similar at the different stations in both years. By

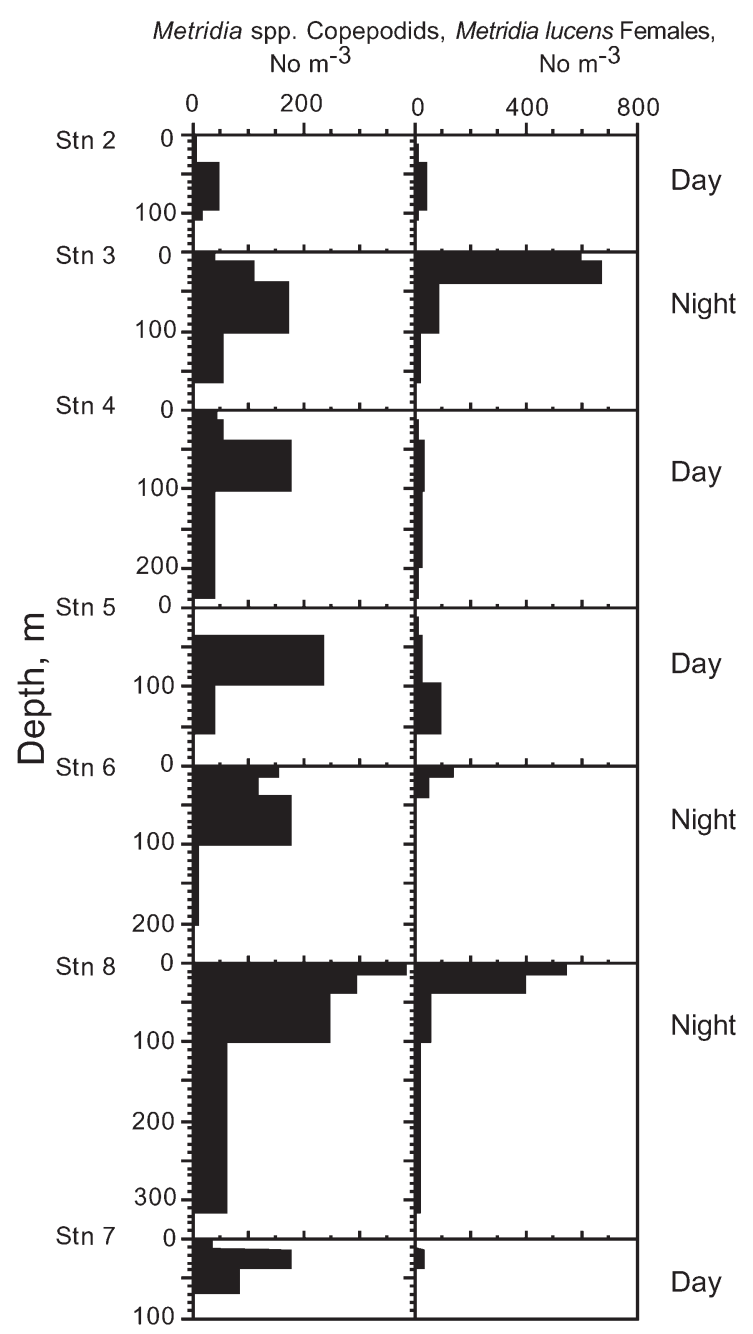

Fig. 8. Depth-distribution of Metridia spp. copepodites and Metridia lucens adult females during February 1999. Abundance is in no. $\mathrm{m}^{-3}$. Time of collection (day vs night) is indicated next to each station

contrast, at the surface there was a striking difference in the condition of adult females among the different stations during the $2 \mathrm{yr}$, especially at the northern and central GOM stations (Fig. 10A,B). In 1999, relative RNA:DNA of the adult females was low near the Maine Coast (Stn 2), but increased at the central GOM stations to values equaling or exceeding those expected under excess food conditions. In contrast, in 2000, adult female relative RNA:DNA was quite low at the coastal station (Stn 9) and increased gradually across the GOM while remaining markedly lower than the ratios observed in 1999. On GB (Stn 15) during 2000 values were similar to those observed in 1999.

EP rates and reproductive status of adult female Calanus finmarchicus corresponded to differences in nutritional status as indicated by the relative RNA: DNA measurements. In 1999, mean EP rates were 

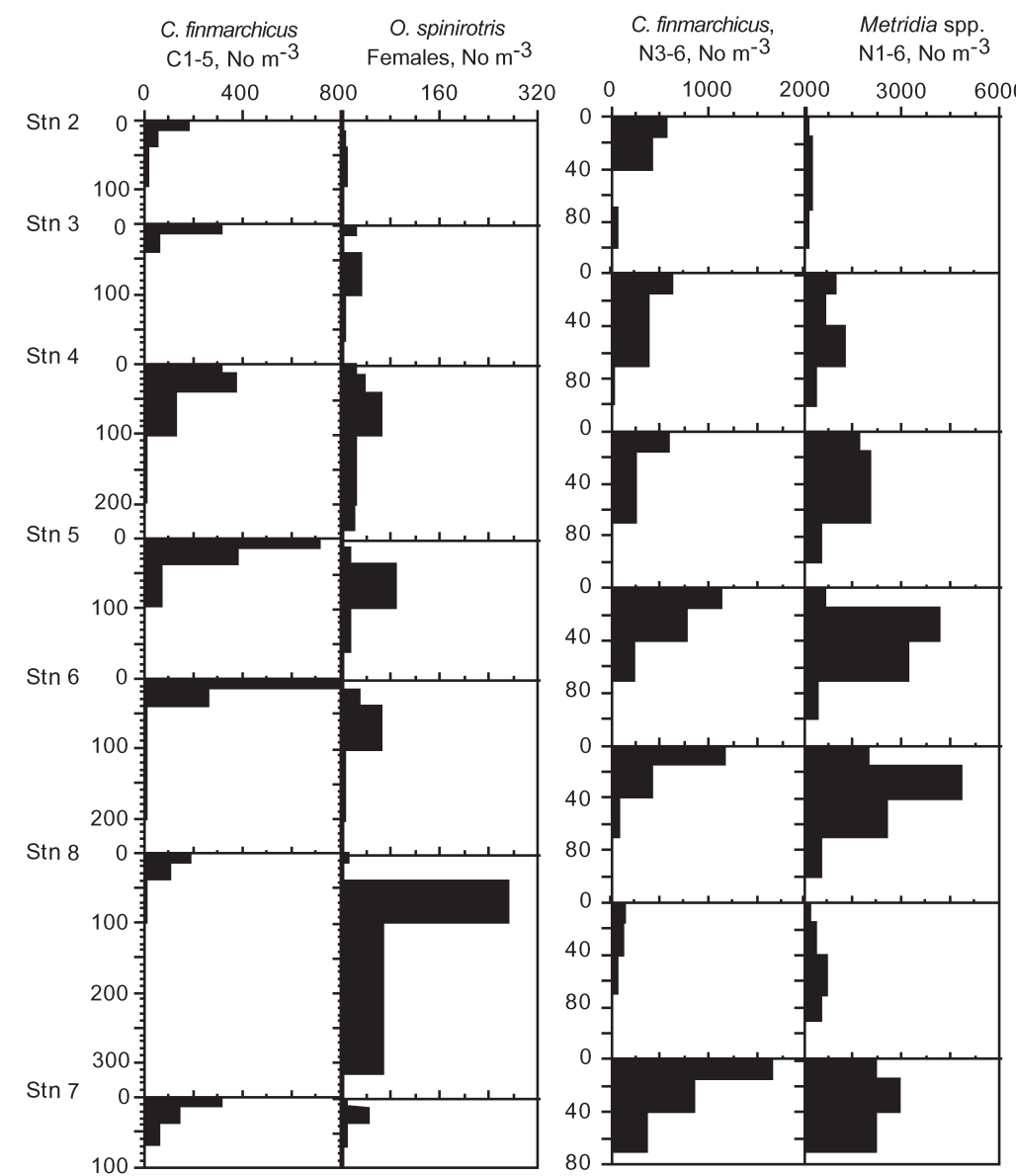

Fig. 9. Depth-distributions of selected taxa during February 1999. Abundance is in no. $\mathrm{m}^{-3}$. Calanus finmarchicus C1-5 (MOCNESS) and N3-6 (pump) are examples of taxa that tend to be close to the surface. In contrast, Oithona spinirostris females (MOCNESS) and Metridia spp. N1-6 are examples of taxa that are deeper in the water column

15 eggs female ${ }^{-1} \mathrm{~d}^{-1}$ at the coastal station (Stn 2) and ranged from 40 to 62 eggs female $\mathrm{e}^{-1} \mathrm{~d}^{-1}$ in the central GOM and on GB (Table 6). In contrast, EP rates in 2000, estimated from the gonadal stage indices, were much lower, increasing across the GOM from low values of 10 to 14 eggs female ${ }^{-1} \mathrm{~d}^{-1}$ in the northern and central regions to about 30 eggs female ${ }^{-1} \mathrm{~d}^{-1}$ in Georges Basin. On GB rates were 45 eggs female ${ }^{-1} \mathrm{~d}^{-1}$ (Fig. 10C).

Mean EP rates of Pseudocalanus spp. at Stns 2 to 5 in the northwestern GOM in 1999 ranged between 1.5 and 4.7 eggs female $\mathrm{e}^{-1} \mathrm{~d}^{-1}$ but were not significantly different (Student-Newman-Keuls [SNK] pairwise comparison; $\mathrm{p}>0.05)$; the overall mean for these stations was 2.8 eggs female ${ }^{-1} \mathrm{~d}^{-1}$. Mean EP rate at the GB station (Stn 7), however, was 7.1 eggs female ${ }^{-1} \mathrm{~d}^{-1}$, 2.5 times higher than the GOM stations (Tukey and SNK pairwise comparison tests; $\mathrm{p}<0.05)$.

Only the reproductive status of the dominant copepods was measured in 2000 and the proportion of
Calanus finmarchicus and Metridia lucens females in mature states of gonad development (GS4) similarly increased along the transect (Fig. 11). Pseudocalanus spp. was only present at the coastal station and on GB during 2000 but at these locations showed the same trends as the other 2 species (Fig. 11). These observations suggest that similar processes influenced reproductive status across a number of copepod species.

The overall relationships of nutritional condition (RNA:DNA) and EP rate of Calanus finmarchicus to the mean concentration of chl a are well described by Ivlev functions (Fig. 12A). In both cases, the critical concentration at which nutritional condition and EP rate become optimal is on the order of $1.5 \mu \mathrm{g} \mathrm{chl} a$ $\mathrm{l}^{-1}$, which is approximately equivalent to the
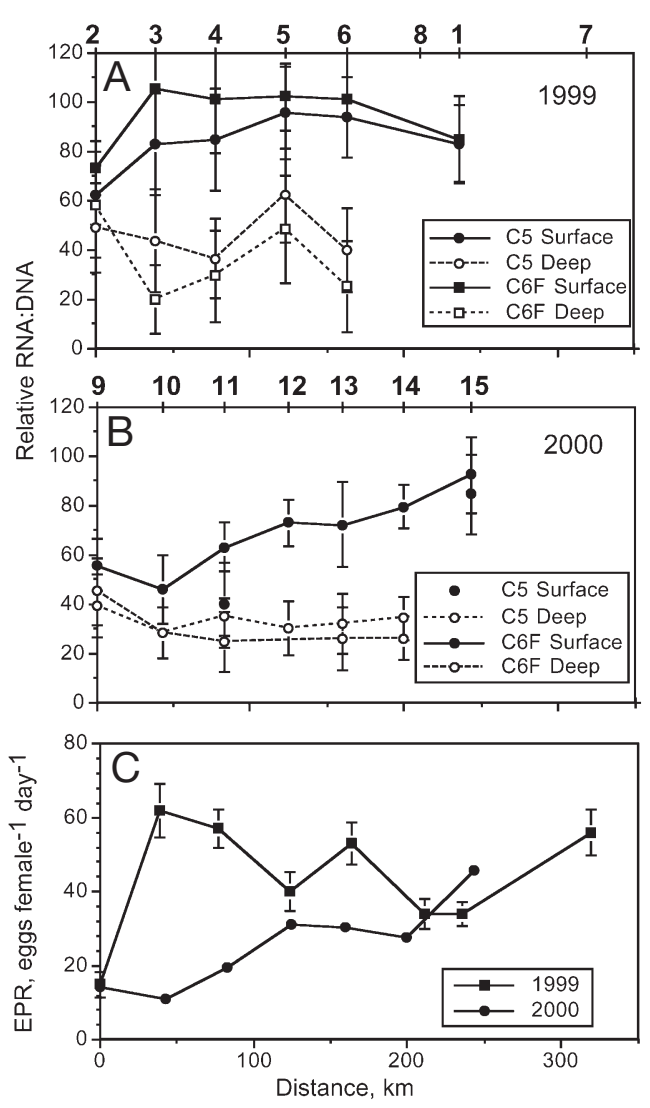

Fig. 10. Calanus finmarchicus. (A,B) Relative RNA:DNA ratios of $\mathrm{C} 5$ and adult females collected from the surface and from at depth in the Gulf of Maine during February 1999 and 2000. Means and standard deviations are indicated. Transect distance is the distance from the first station adjacent to the Maine coast. Station numbers are shown at the top of each figure. (C) Egg production rates of C. finmarchicus during February 1999 (measured) and February 2000 (estimated from the Reproductive Index, Niehoff \& Runge unpubl.) 
$75 \mathrm{mg}$ chl a $\mathrm{m}^{-2}$ critical concentration observed for $C$. finmarchicus on $\mathrm{GB}$ during US GLOBEC 1995-1997 process cruises (J. A. Runge, S. Plourde, P. Joly, E. Durbin, B. Niehoff unpubl.). In $1999 \mathrm{chl}$ a was above the critical concentration for maximal RNA:DNA ratios and reproductive rates at all but 1 station (Stn 2), whereas in $2000 \mathrm{chl} \mathrm{a}$ concentrations were below saturating conditions at all but 1 station (Stn 15). This is strong evidence that the high rates of growth and reproductive activity of C. finmarchicus during February 1999 were related to the presence of the winter bloom.

The mean hatching percentage of Calanus finmarchicus eggs spawned during incubations in 1999 ranged from $63 \%$ at Stn 3 to $92 \%$ at Stn 1 (Table 6). Hatching was significantly higher at the 2 GB stations (Stns 1 and 7) than at GOM Stn 3 (1-way ANOVA, Tukey and SNK pairwise tests: p < 0.05). Hatching success at stations in the central GOM (Stns 4, 5, 6 and 8) was not significantly different (1-way ANOVA $; \mathrm{p}=0.194)$, with an overall mean of $78 \%$.

The EP rates of adult female Calanus finmarchicus were directly related to the RNA:DNA ratios. Combining data for 1999 and 2000 showed a strong linear relationship of mean EP rates at each station with the mean relative RNA:DNA ratio (Fig. 13). The slope and $y$-intercept of these EP-RNA:DNA functions were not significantly different from those observed for $C$. finmarchicus in the GB region between January and June 1995 (ANCOVA p > 0.05, Wagner 2000). This suggests that the relationship of reproductive rates and RNA:DNA ratios is similar from year to year in this region. The linear relation between $C$. finmarchicus EP rates and RNA:DNA ratios indicates that the RNA:DNA ratios are a good indicator of EP rates as noted previously by Saiz et al. (1998) for Acartia grani.

Median mortality rates for Calanus finmarchicus in the 2 winters are illustrated in Fig. 14. For both years, the estimates assume that the stage structure of the population observed in Fig. 7 was constant for a period of time corresponding to the development time from egg through N6, i.e. at least 24 to $28 \mathrm{~d}$. This assumption appears reasonable in 1999, where there is no pronounced cohort structure. If the stage structure of the
Table 5. Median WMD (m) for abundant taxa at Gulf of Maine (GOM) stations igned ranks $(1=0-35 \mathrm{~m}, 2=36-45 \mathrm{~m}, 3=46-60 \mathrm{~m}, 4=61-100 \mathrm{~m}, 5=$ $>100 \mathrm{~m}$ ). WMD values for 2000 and their ranks illustrate differences in depths between years. $\mathrm{N}=$ nauplii, $\mathrm{C}=$ copepodids, $\mathrm{A}=$ adults, $\mathrm{F}=$ adult females, $\mathrm{M}=$ adult males, $\mathrm{nd}=$ no data

\begin{tabular}{|c|c|c|c|c|}
\hline \multirow[t]{2}{*}{ GOM stations } & \multicolumn{2}{|c|}{$-1999-$} & \multicolumn{2}{|c|}{$2000-$} \\
\hline & Median & Rank & Median & Rank \\
\hline Calanus finmarchicus, $\mathrm{N}$ & 29 & 1 & 46 & 2 \\
\hline Calanus finmarchicus, C & 24 & 1 & 116 & 5 \\
\hline Calanus finmarchicus, $\mathrm{F}$ & 29 & 1 & 34 & 1 \\
\hline Centropages spp., N & 35 & 1 & 37 & 2 \\
\hline Centropages spp., C & 33 & 1 & 31 & 1 \\
\hline Centropages typicus, F & 23 & 1 & nd & nd \\
\hline Centropages typicus, M & 19 & 1 & nd & nd \\
\hline Pseudocalanus spp., C & 34 & 1 & 46 & 3 \\
\hline Chaetognaths & 23 & 1 & 76 & 4 \\
\hline Limacina spp. & 34 & 1 & 75 & 4 \\
\hline Metridia spp., N & 44 & 2 & 51 & 3 \\
\hline Oithona spp., N & 40 & 2 & 56 & 3 \\
\hline Oithona spp., C & 40 & 2 & 57 & 3 \\
\hline Oithona spp., F & 38 & 2 & 77 & 4 \\
\hline Oithona spp., M & 42 & 2 & 67 & 4 \\
\hline Paracalanus parvus, F & 38 & 2 & 33 & 1 \\
\hline Pseudocalanus spp., N & 42 & 2 & 49 & 3 \\
\hline Pseudocalanus spp., F & 40 & 2 & 57 & 3 \\
\hline Pseudocalanus spp., M & 45 & 2 & nd & nd \\
\hline Clauso./Paracalanus, $\mathrm{N}$ & 57 & 3 & 60 & 3 \\
\hline Clauso./Paracalanus, C & 48 & 3 & 45 & 2 \\
\hline Clausocalanus arcuicornis, F & 58 & 3 & nd & nd \\
\hline Clausocalanus arcuicornis, M & 58 & 3 & 74 & 4 \\
\hline Metridia lucens, F & 50 & 3 & 61 & 4 \\
\hline Microsetella norvegica, $\mathrm{N}$ & 54 & 3 & 47 & 3 \\
\hline Microsetella norvegica, C \& A & 51 & 3 & 52 & 3 \\
\hline Polychaetes & 87 & 3 & 135 & 5 \\
\hline Calanus finmarchicus, $\mathrm{M}$ & 68 & 4 & 117 & 5 \\
\hline Metridia spp., C & 71 & 4 & 97 & 4 \\
\hline Microcalanus pusillus, $\mathrm{F}$ & 82 & 4 & nd & nd \\
\hline Microcalanus pusillus, M & 96 & 4 & nd & nd \\
\hline Oithona spinirostris, $\mathrm{F}$ & 72 & 4 & 100 & 4 \\
\hline Oncaea spp., C \& A & 63 & 4 & 63 & 4 \\
\hline Metridia lucens, M & 112 & 5 & 118 & 5 \\
\hline
\end{tabular}

population in winter 2000 instead reflected a prior recruitment pulse of early developmental stages that had not fully matured, then the mortality estimates in Fig. 14 for 2000 would be invalid. If, however, the stage structure observed in February 2000 was at steady state, then the envelope of mortality rates in Fig. 14 would imply markedly higher mortality rates of late naupliar stages in winter 2000 than in winter 1999.

\section{DISCUSSION}

These results document how large interannual differences in winter phytoplankton abundance in the GOM dramatically influence zooplankton abundance 


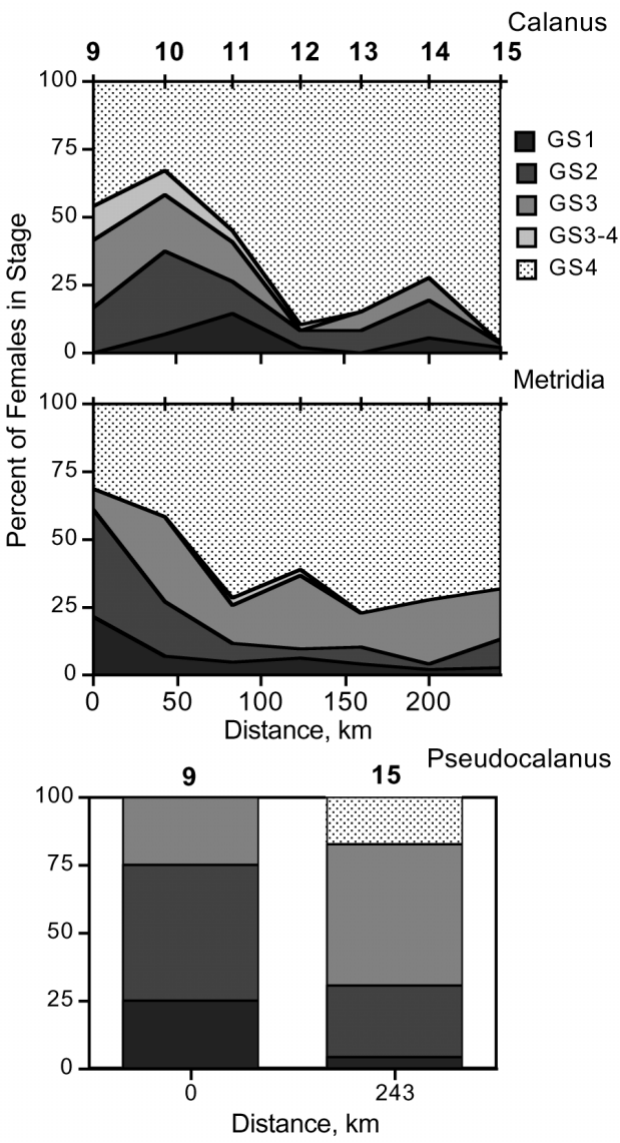

Fig. 11. Gonad stages of Calanus finmarchicus, Metridia lucens and Pseudocalanus sp. during February 2000. Transect distance is the distance from the first station adjacent to the Maine coast.

Station numbers are shown at the top of each figure

and productivity. We suggest that these differences, in turn, will have large effects on downstream regions such as GB. Both phytoplankton and zooplankton appeared to be responding to hydrographic changes between years. It appears that during late fall or early winter of 1999, a large influx of cooler, less salty, Scotian Shelf water to the eastern GOM provided the stability necessary for a phytoplankton bloom. This winter bloom supported high zooplankton population growth rates and provided a source of what are normally coastal or bank zooplankton species to the central Gulf. In contrast, during 2000, with no distinct presence of Scotian Shelf water, there was a more typical deep winter mixing and low phytoplankton and zooplankton abundance.

The presence of the phytoplankton bloom during winter of 1999 appears to be an unusual phenomenon in this region. Examination of 1998-1999 SeaWiFS images suggests that the phytoplankton bloom was in progress for some time prior to the 1999 winter cruise, as high surface chl a was observed from December onwards (J. O'Reilly pers. comm.). Prior to the initiation of the spring bloom in the GOM phytoplankton levels are normally low with concentrations $<0.5 \mu \mathrm{g} \mathrm{l}^{-1}$ (Durbin et al. 1995, O'Reilly \& Zetlin 1998); the same level as observed during winter 2000. The bloom in the GOM typically begins in late March and continues through April (Bigelow 1926, Townsend \& Spinrad 1986, Durbin et al. 1995, O'Reilly \& Zetlin 1998). During the 10 yr MARMAP (Marine monitoring and prediction) program carried out by the US National Marine Fisheries Service (1977 to 1988) there was no evidence of anomalously high chl a concentrations either in Jordan or Georges Basin during winter (O'Reilly \& Zetlin 1998), although these regions appeared to have been sampled during winter in only 3 out of $10 \mathrm{yr}$.

The timing of the onset of the winter-spring bloom is considered to be controlled by light when the critical depth becomes less than the mixed layer depth. Usually this occurs by thermal stratification when solar insolation increases during April. On the nearby southwestern Scotian Shelf, a mixed-layer model incorporating surface heating, differential advection, and turbulent dissipation by wind and tide, showed transient periods of stratification during late winter and early spring (Perry et al. 1989). The patterns of mean mixed-layer light intensities calculated from the modeled mixed-layer depths were significantly correlated with observed chl a biomass, and they suggested that the transient stratification events were partially responsible for the higher chl a biomass in 1 of the 3 years studied. However, in the GOM during winter the estimated critical depth was very shallow (11 to $25 \mathrm{~m}$ ), much less than the mixed-layer depth we observed; the bloom observed in 1999 occurred prior to any significant development of stratification through solar

Table 6. Calanus finmarchicus. Summary of egg production data for February 1999. EPR denotes egg production rate (eggs female ${ }^{-1} \mathrm{~d}^{-1}$ ) and clutch size is mean eggs female ${ }^{-1}$. Standard error in parentheses $(\mathrm{n}=36-40)$. Hatch success represents percentage of eggs hatching to nauplii. Standard error ( $\mathrm{n}=16$ at Stn $1 ; \mathrm{n}=4-5$ elsewhere) in parentheses. No data for Stns 2 and 9. Local time at the start of each experiment is shown

\begin{tabular}{|lccccc|}
\hline $\begin{array}{l}\text { Date } \\
(1999)\end{array}$ & Stn & $\begin{array}{c}\text { Time } \\
(\mathrm{h})\end{array}$ & EPR & $\begin{array}{c}\text { Clutch } \\
\text { size }\end{array}$ & $\begin{array}{c}\text { Hatch } \\
\text { success (\%) }\end{array}$ \\
\hline $23 \mathrm{Feb}$ & 1 & $14: 00$ & $34(3.3)$ & $40(3.0)$ & $92(2.2)$ \\
$27 \mathrm{Feb}$ & 2 & $13: 10$ & $15(3.4)$ & $39(3.5)$ & - \\
$27 \mathrm{Feb}$ & 3 & $20: 20$ & $62(7.3)$ & $53(2.6)$ & $63(8.3)$ \\
$28 \mathrm{Feb}$ & 4 & $09: 20$ & $57(5.3)$ & $48(2.3)$ & $79(3.6)$ \\
$28 \mathrm{Feb}$ & 5 & $14: 10$ & $40(5.2)$ & $49(3.0)$ & $79(2.5)$ \\
$28 \mathrm{Feb}$ & 6 & $20: 00$ & $53(5.6)$ & $49(2.4)$ & $80(2.6)$ \\
02 Mar & 7 & $11: 15$ & $56(6.2)$ & $45(2.9)$ & $86(2.9)$ \\
02 Mar & 8 & $21: 30$ & $34(3.9)$ & $36 .(2.7)$ & $72(1.8)$ \\
03 Mar & 9 & $10: 35$ & $55(6.1)$ & $46(3.1)$ & - \\
\hline
\end{tabular}



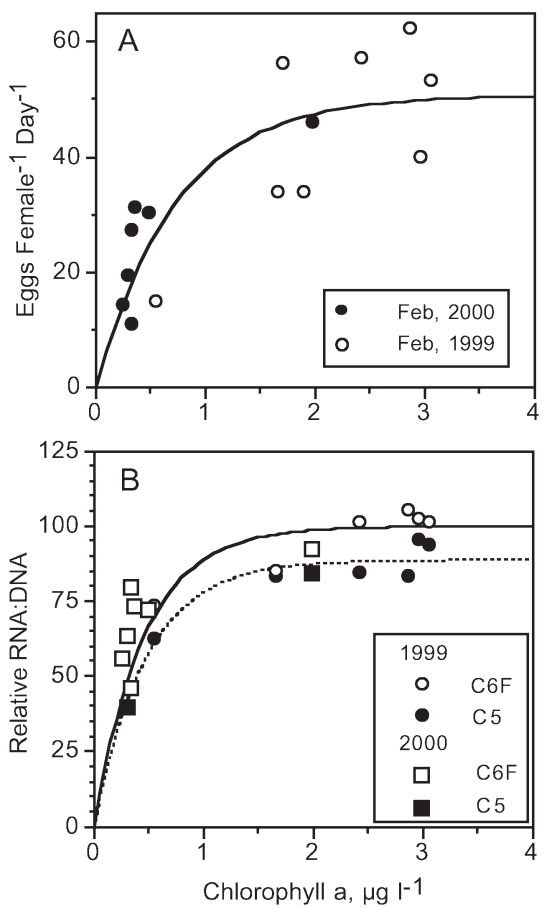

Fig. 12. Calanus finmarchicus. (A) Relationship between total chl a (mean for the water column depth over which the copepods were collected) and egg production rate for near-surface collected adult females during February 1999 (measured) and 2000 (estimated from the Reproductive Index, Niehoff \& Runge unpubl.). Curves show the relationship between EP and chl $a$ for both years together. EPR $=50.7(1-\exp [-1.38 \times$ chl a]). (B) Relationship between relative RNA:DNA and total chl a (mean for the water column depth over which the copepods were collected) for near-surface collected $C$. finmarchicus C5 and adult females during February 1999 and 2000. Curves show the relationship between RNA:DNA and chl a for C5 and adult females collected during both years. For C5 Rel RD = 88.64 $(1-\exp [-2.12 \times$ chl a $])$ while for C6 Rel RD = $99.8(1-\exp [-2.21 \times \mathrm{chl} a])$

insolation. Other possible explanations for the presence of the bloom during this year include: (1) weak or absent wind-driven vertical mixing, which could allow development of a bloom even when the mixed-layer depth is considerably greater than the critical depth (Townsend et al. 1992), (2) upward doming of dense slope water in the central GOM resulting in a shallower pycnocline (Townsend \& Spinrad 1986), or (3) advection into the GOM of a shallow layer of less dense water providing stratification.

The suggestion of transient stratification was based on the observation of high chl a concentrations in the GOM during winter when the mixed-layer depth was much deeper than the critical depth (Townsend et al. 1992). However, examination of the wind fields during the 2 years of our study do not indicate sufficient differences between years that would have allowed the development of a bloom in 1999 but not in 2000 (J. Manning pers. comm.).

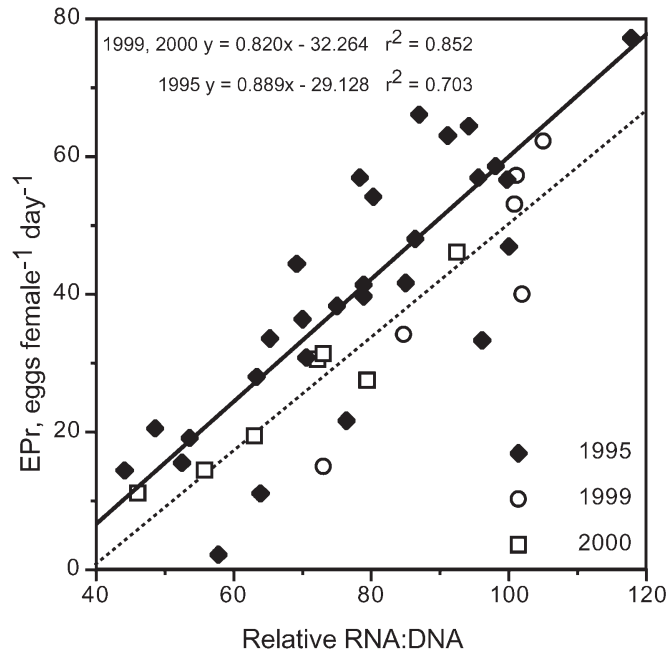

Fig. 13. Calanus finmarchicus. Relationship between adult female egg production rate (EPR) and relative RNA:DNA for all of the data collected during February 1999 and 2000 in the Gulf of Maine. For comparison, the relationship between EP and relative RNA:DNA is shown for Calanus finmarchicus collected on Georges Bank during the winter-spring period of 1995 (from Wagner 2000)

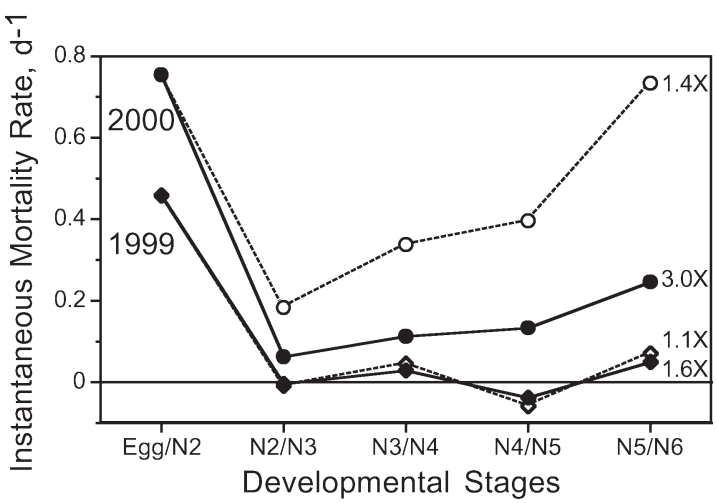

Fig. 14. Calanus finmarchicus. Estimated median instantaneous mortality rates in February 1999 (assuming stage durations ranged from 1.1 to $1.6 \times$ Belehradek development times in Campbell et al. 2001b), and February 2000 (assuming stage durations ranged from 1.4 to $3 \times$ development times in Campbell et al. 2001b). Estimates further assume that the stage structure is at steady state

In an analysis of anomolously high chl a levels during late March in the Jordan Basin, Townsend \& Spinrad (1986) suggested that an intrusion and subsequent upward doming of dense slope water caused the pycnocline to be present at 90 to $100 \mathrm{~m}$. This was calculated to be the critical depth during mid-March (assuming maximal surface irradiance with no cloud cover). While doming of bottom water in both the Jordan and Georges Basins was observed during each year of our study, the depth of the pycnocline was much greater than our estimates of winter critical 
depth and consequently would not have promoted phytoplankton growth. Moreover, the effects of the deep water intrusions on pycnocline depth were actually opposite to the observed trends in phytoplankton. During 2000 a large mass of warm, salty slope water was present within $90 \mathrm{~m}$ of the surface and a very strong pycnocline occurred between 60 and $90 \mathrm{~m}$. In winter 1999, on the other hand, the bottom water, a remnant of Labrador Slope water that had entered into the GOM during the spring of 1998 (Drinkwater et al. 1999), was cooler and less salty. During this year the pycnocline was deeper and less pronounced.

Surface waters of the eastern GOM are heavily influenced by advective inputs of cold and fresher Scotian Shelf water around Cape Sable (Smith 1983). Because of this advective influence, Mountain et al. (1996) found no correlation between variations in water temperature in the eastern GOM and heat flux. While the presence of the Scotian Shelf water in 1999 did not have a major effect on mixed layer depth during the study period, we suggest that the initial spread of Scotian Shelf water across the eastern GOM during early 1999 resulted in a shallow surface mixed layer, allowing the bloom to develop. For example, at Stn 14 during February 2000, which was in the plume of lower salinity water entering the Gulf, the mixed-layer depth was relatively shallow $(<40 \mathrm{~m})$. Subsequently, this shallow surface layer was mixed down to the depth observed during the 1999 cruise. This hypothesis points to the significance of processes controlling inflow of Scotian shelf water into the central GOM on the region's phytoplankton bloom dynamics. A similar important role of advection was found in a model of the development of the spring bloom off southwest Nova Scotia (Perry et al. 1989).

The between-year differences in abundance of zooplankton in the GOM resulted from interannual differences in advective supply of copepods to the central GOM and in the productivity of copepods present in the GOM. These productivity differences were the result of the interannual differences in phytoplankton described above.

The influx of Scotian Shelf water to the central GOM in 1999 carried with it zooplankton species which are not normally found in abundance in this region during winter. A group including Pseudocalanus spp., Centropages typicus and C. hamatus were abundant in 1999 in the central GOM but were only present in a plume of Scotian Shelf water in Georges Basin, on GB and in coastal waters of the northern GOM during 2000. These 3 taxa are not typically present in the central GOM during winter (Jossi \& Kane 2000), but are present on the Scotian Shelf (Tremblay \& Roff 1983), on GB (Davis 1987) and in coastal waters of the GOM (Bigelow 1926). Both Centropages species lay resting eggs which sink to the bottom (Marcus 1996) causing their association with shallow coastal or bank regions. There are 2 species of Pseudocalanus: P. moultoni, which tends to be more inshore in the GOM, and $P$. newmani, which originates from the Scotian Shelf and tends to be more offshore (Frost 1989, McLaren et al. 1989a). The low abundance of these taxa in the central GOM observed during 2000 is the more typical pattern for these species (Jossi \& Kane 2000). The higher abundance of Pseudocalanus spp. in the central GOM in 1999 and at Stn 14 in the plume of Scotian Shelf water in 2000 were probably seeded from the Scotian Shelf and are thus likely to be $P$. newmani.

A second group of small copepods, including Microcalanus pusillus, Microsetella norvegica, Oithona spinirostris and Oithona spp., were also abundant in 1999 but low at all stations in 2000, except in the plume of Scotian Shelf water in Georges Basin. There is little information about these species in the GOM because their small size has led to inadequate sampling in prior studies. However, they are observed in Scotian Shelf waters (Tremblay \& Roff 1983) and their presence in abundance only in the Scotian Shelf plume during 2000 would also indicate a Scotian Shelf origin during 1999.

Adult Calanus finmarchicus and Metridia lucens were most abundant in the central GOM and lower in abundance in coastal waters and on GB. While $M$. lucens follows the same pattern as seen in the other smaller copepods with a greater abundance of adults during 1999, C. finmarchicus adults were more abundant during 2000. These 2 species appear to have different sources. While the Scotian Shelf-GOM shelf populations of $C$. finmarchicus may ultimately be supplied from slope populations (Head et al. 1999) with possibly some input from the Gulf of St. Lawrence, the immediate source of adult $C$. finmarchicus present in the GOM during winter is the local diapausing population in the GOM's deep basins. As a result, abundance of adult females at the surface during early winter is determined by the size of the resting population returning to the surface rather than by advective events. The higher abundance of adult females during 2000 reflects a greater abundance of resting animals during the previous fall. This is supported by the observation of a very low abundance of resting $C$. finmarchicus in the deep basins of the GOM during the fall of 1998 compared to the fall of 1999 (C. Greene \& P. Wiebe pers. comm.). Our data indicate that $C$. finmarchicus resides close to the surface once they emerge from diapause; models predict that C. finmarchicus in surface waters of the GOM will be rapidly exported onto GB by surface currents (Hannah et al. 1998, Miller et al. 1998). As the winter progresses, the central GOM populations must be re-supplied through 
advective processes, with the Scotian Shelf serving as an important source (Lynch et al. 1998, Miller et al. 1998).

Metridia lucens is more abundant in deeper shelf regions and lower in abundance on shallow banks such as Browns Bank (McLaren et al. 1989b) and GB (Kane 1993, Perry et al. 1993). It does not have a deep resting stage and thus the population in the central GOM requires advective input. The much greater abundance during 1999 associated with the Scotian Shelf water influx, and the greater abundance at Stn 14 during 2000, where a plume of Scotian Shelf water was present, suggest a Scotian Shelf origin rather than an influx with slope water through the NE Channel. Not much is known about the population dynamics of this species in the GOM. McLaren et al. (1989b) found that development ceases at C5 and adult in late fall on the nearby Scotian Shelf, and that reproduction does not recommence until the following spring, when the phytoplankton spring bloom develops. The very low population levels during 2000, together with low reproductive rates and an absence of intermediate developmental stages, indicate that this species normally follows a similar pattern in the central GOM during winter. The strong diel vertical migration by the adult Metridia lucens, together with the observation that the younger stages occupy a wide depth range and not just the immediate surface layer, suggest that it will be less rapidly advected out of the region and onto GB than C. finmarchicus (Gentleman 2000).

There were pronounced differences in zooplankton productivity between years with much higher levels during 1999 reflecting the high phytoplankton levels present. This is seen in the much greater abundance of younger developmental stages of most taxa during 1999 compared with 2000, the higher observed EP rates and RNA:DNA levels of Calanus finmarchicus, as well as in the gonadal indices of other copepod species. In contrast to these large differences observed in the GOM, zooplankton productivity was high in both years on $\mathrm{GB}$, reflecting the normally high phytoplankton levels there during the winter (O'Reilly \& Zetlin 1998).

RNA:DNA ratio, a good indicator of growth rate for Calanus finmarchicus (Wagner et al. 2001), showed a strong correlation with chl a for surface C5 and adult females, and between-year differences in RNA:DNA ratios reflected the between year differences in food availability. In contrast, RNA:DNA ratios of deep C5 and adult females were always very low, indicating individuals in diapause (Wagner 2000). Interestingly, the 1 surface C5 sample taken from the central GOM during 2000 showed values more typical of diapause, whereas surface RNA:DNA ratios in 1999 were rela- tively high, indicating animals growing at near maximal rates. We suggest that the surface C5 in 1999 originated from the actively growing G1 cohort and that in 2000 the surface stage $\mathrm{C} 5$ were overwintering animals in the process of emerging from diapause. Consistent with this interpretation, the population age structure shows the presence of all developmental stages through stage C5 in winter 1999, but no younger copepodid stages in 2000. In addition, in 1999 a relatively small proportion $(20 \%)$ of the stage C5 population resided at depths $>100 \mathrm{~m}$, whereas the opposite $(70 \%$ stage C5 at depth) was observed in 2000.

EP rates of Calanus finmarchicus exhibited a similar relationship to available food as that described above for RNA:DNA. Rates were much lower in the central GOM in 2000 compared with 1999, supporting the suggestion of a strong food limitation during pre-bloom conditions in 2000. Gonad stage indices for Metridia lucens and Pseudocalanus spp. showed the same trends as C. finmarchicus, indicating that they also were responding to differences in food availability. Although EP rates for $C$. finmarchicus were reduced during 2000 , they were not reduced as greatly as may have been expected given the very low food levels (total chl $a<0.5 \mathrm{\mu g} \mathrm{l}^{-1}$, $>5 \mu \mathrm{m}$ chl a essentially zero), and our observations on GB during a post-spring bloom period when EP ceased while total chl a was around $0.5 \mathrm{\mu g} \mathrm{l}^{-1}$ (Campbell et al. 2001a). A conclusion might be that EP by females, just after they emerge from diapause in winter and early spring, depends more on internal sources of energy than on external sources (Irigoien et al. 1998). However, there is conflicting evidence on this issue at present. In the Gulf of St. Lawrence (Plourde \& Runge 1993) and in the Norwegian Sea (Melle \& Skjoldal 1998), no eggs were spawned until the development of the phytoplankton bloom. In the Gulf of St. Lawrence, pre-bloom food limitation was demonstrated, as non-egg-producing females captured before the spring bloom and maintained in high food levels in the laboratory produced eggs well before their field counterparts. In contrast, significant rates of EP by $C$. finmarchicus have been observed at pre-bloom chl a concentrations of only 0.2 to $0.4 \mathrm{~g} \mathrm{l}^{-1}$ (Niehoff et al. 1999, Richardson et al. 1999, this study). In 2 of these studies, measured (Irigoien et al. 1998) and estimated (Richardson et al. 1999) ingestion rates were insufficient to cover the energetic costs of EP. It is possible that in this species of Calanus, internal lipid stores provide most of the energetic requirements and some level of ingested material is required for gonad maturation and subsequent egg production (Ohman \& Runge 1994, Niehoff et al. 1999). Consistent with this interpretation, the spawning rates predicted in winter of 2000 in the GOM fit with Ivlev relationships relating chl a biomass to EP in this region 
(Fig. 12). Additional studies of ingestion rate and EP by C. finmarchicus during pre-bloom periods are needed to resolve this issue.

Egg hatching success at all stations was relatively high, consistent with observations of Calanus finmarchicus and other species in other regions (Irigoien et al. 2002). The finer-scale (but significant) differences in hatching percentage between stations on GB and in the GOM in winter 1999 (medians of 89 and $79 \%$, respectively) may reflect differences in female condition or food quality between the GB and the GOM, possibilities that would be amenable to experimental study in the future.

Despite the reduced EP rates during 2000, the relatively large numbers of Calanus finmarchicus naupliar stages N1-3 in 2000 are the manifestation of relatively high population EP rates (i.e. eggs $\mathrm{m}^{-2} \mathrm{~d}^{-1}$ ) due to the greater abundance of females. This illustrates the importance of female abundance in the regulation of population EP rates. A similar effect, where high abundance of adult females results in high population EP rates despite food limitation of EP rates, has been observed in the Norwegian Sea by Niehoff et al. (1999).

The stage of development of the Calanus finmarchicus populations were very different between the 2 years. During 1999 large numbers of all stages were present and the leading edge of the cohort had reached $\mathrm{C} 5$. In contrast, there were few individuals older than N3 during 2000. The paucity of N4 to C3 stages in February 2000 could be due to 2 different processes: (1) delayed maturation and delayed initiation of egg production in food-limited conditions, or (2) severe starvation-induced mortality of the feeding naupliar stages. Indeed, both processes could be operating. In the GOM C. finmarchicus emerges from diapause during late December and begins reproduction in early January (Durbin et al. 1997). During the GB GLOBEC study several stations were sampled in the GOM adjacent to GB each month between January and June 1995 to 1999, and there was a consistent pattern of molting from overwintering $\mathrm{C} 5$ to adults in January with little variation in the proportion of stages present between years (E. G. Durbin unpubl.). This would suggest that delayed maturation during 2000 is unlikely. If $\mathrm{C} 5$ copepodids molted to adult at the normal time in 2000, an even lower level of phytoplankton than the already low level we observed in 2000 would be required to delay initiation of EP. This is unlikely. Elevated starvation-induced mortality rates of the feeding naupliar stages would be consistent with the evidence above for food limitation of per capita EP in 2000 and the low RNA:DNA ratios. However, in the absence of information on the recruitment schedule of C. finmarchicus prior to our arrival in the GOM we have no means of distinguishing between food limita- tion effects that retarded cohort development and food limitation effects that caused severe mortality of late naupliar stages. These results highlight the need for continuous temporal analysis of population changes, such as would be generated by a high frequency shipboard measurement program or moored zooplankton sensors. The mortality rates observed in the GOM in 1999 are consistent with those observed for C. finmarchicus on GB (Ohman et al. 2002). The rates inferred for 2000, if not biased by a temporal pulse of development, are appreciably higher than those measured on GB. The elevated mortality of $C$. finmarchicus eggs and young nauplii in winter 2000 is also consistent with the higher abundance of adult females and the hypothesized role of adult females as cannibals of eggs and early nauplii (Ohman \& Hirche 2001, Ohman et al. 2002).

The winter phytoplankton bloom may have allowed an additional generation of Calanus finmarchicus to take place in the GOM prior to the generation that develops in response to the March-April spring bloom in more normal years. Our results indicate that $C$. finmarchicus is normally food-limited in the GOM during winter after it emerges from diapause. This would delay the development of the population as suggested by Lynch et al. (1998). A consequence of this early 1999 generation would be to overcome the effects of the very low abundance of resting C5 C. finmarchicus observed in the deep basins of the GOM during the fall of 1998 by C. H. Greene \& P. H. Wiebe (pers. comm.). Early emergence of $C$. finmarchicus from diapause in the GOM allows the population to take advantage of interannual variability in the timing of production of sufficient food for successful reproduction.

The GOM serves as an important source for seed populations of zooplankton advected onto GB (Durbin et al. 1997, 2000). Thus, zooplankton production processes during the winter in the GOM will have effects on GB. Observations (Meise \& O'Reilly 1996, Durbin et al. 1997, 2000) and modeling studies (Lynch et al. 1998, Miller et al. 1998, Hannah et al. 1998) indicate that Calanus finmarchicus is normally absent or present in only very low abundance on GB in late fall. The abundance of $C$. finmarchicus on GB during the winter and spring of 1999 were not unusually low compared to other GLOBEC study years (E. G. Durbin unpubl.), suggesting that the early development of the $C$. finmarchicus population in the GOM overcame the potential effects of the very low abundance of resting $\mathrm{C} 5$ in the GOM the previous fall.

Populations of Pseudocalanus spp. on GB are similarly seeded from off-bank sources (Davis 1984, McGillicuddy et al. 1998). Population sources for $P$. moultoni appear to be the inshore regions of the western GOM, whereas the source of $P$. newmani is likely 
via Scotian Shelf water crossing over to GB. The presence of a large population of Pseudocalanus spp. across the central GOM during 1999 suggests that there was much greater seeding of GB during that year. Results from the US GLOBEC GB study indicate that the highest abundance of Pseudocalanus spp. on GB occurred during April 1999 compared to any of the other 4 GLOBEC years (E. G. Durbin unpubl.). Enhanced seeding of GB due to interannual variation in advective processes and winter phytoplankton blooms in the GOM could have important implications for higher trophic levels on GB, particularly larval cod and haddock, which hatch out during late winter and feed on copepod nauplii.

Acknowledgements. We wish to thank Dave Townsend for the nutrient analyses during 2000, Pierre Joly for assistance at sea and Lucienne Chenard for laboratory analyses. This research was supported by the Nation Science Foundation (OCE9806506) and by Fisheries and Oceans, Canada. This is contribution no. 363 of the US GLOBEC GB program sponsored jointly by NSF and NOAA.

\section{LITERATURE CITED}

Aksnes DL, Ohman MD (1996) A vertical life table approach to zooplankton mortality estimation. Limnol Oceanogr 41: 1461-1469

Bigelow HB (1926) Plankton of the offshore waters of the Gulf of Maine. Bull Bur Fish, Wash, DC 40:1-509

Campbell RG, Runge JA, Durbin EG (2001a) Evidence for food limitation of Calanus finmarchicus production rates on the southern flank of Georges Bank during April 1997. Deep-Sea Res II 48:531-549

Campbell RG, Wagner MM, Teegarden GJ, Boudreau CA, Durbin EG (2001b) Growth and development of Calanus finmarchicus in the laboratory. Mar Ecol Prog Ser 221: 161-183

Davis CS (1984) Food concentrations on Georges Bank: nonlimiting effect on development and survival of laboratory reared Pseudocalanus sp. and Paracalanus parvus (Copepoda: Calanoida). Mar Biol 82:41-46

Davis CS (1987) Zooplankton life cycles. In: Backus RH (ed) Georges Bank. MIT Press, Cambridge, MA, p 256-267

Drinkwater KF, Mountain DB, Herman A (1999) Variability in the slope water properties off eastern North America and their effects on the adjacent shelves. ICES C.M. 1999/O:08, $26 \mathrm{p}$

Durbin EG, Durbin AG, Beardsley RC (1995) Springtime nutrient and chlorophyll a concentrations in the southwestern Gulf of Maine. Cont Shelf Res 15:433-450

Durbin EG, Runge JA, Campbell RG, Garrahan PR, Casas MC, Plourde S (1997) Late fall-early winter recruitment of Calanus finmarchicus on Georges Bank. Mar Ecol Prog Ser 151:103-114

Durbin EG, Garrahan PR, Casas MC (2000) Abundance and distribution of Calanus finmarchicus on Georges Bank during 1995 and 1996. ICES J Mar Sci 57:1664-1685

Fish CJ, Johnson MW (1937) The biology of the zooplankton production in the Bay of Fundy and Gulf of Maine with special reference to production and distribution. J Biol Board Can 3:189-322
Gentleman WC (2000) Factors controlling the seasonal abundance and distribution of Calanus finmarchicus in the Gulf of Maine/Georges Bank region. PhD thesis, Dartmouth College, Hanover, New Hampshire

Gran HH, Braarud T (1935) A quantitative study of the phytoplankton in the bay of Fundy and the Gulf of Maine (including observations on hydrography, chemistry and turbidity). J Biol Board Can 1:279-467

Frost BW (1989) A taxonomy of the marine calanoid copepod genus Pseudocalanus. Can J Zool 67:525-551

Hannah CG, Naimie CE, Loder JW, Werner FE (1998) Upperocean transport mechanisms from the Gulf of Maine to Georges Bank, with implications for Calanus supply. Cont Shelf Res 17:1887-1911

Head EJH, Harris LR, Petrie B (1999) Distribution of Calanus spp. on and around the Nova Scotia Shelf in April-evidence for offshore source of Calanus finmarchicus to the mid- and western regions. Can J Aq Sci 56:2463-2476

Hitchcock GC, Smayda TJ (1977) The importance of light in the initiation of the 1972-1973 winter-spring diatom bloom in Narragansett Bay. Limnol Oceanogr 22:126-131

Irigoien X, Head R, Klenke U, Meyer-Harms B, Harbour D, Niehoff B, Hirche HJ, Harris R (1998) A high frequency time series at weathership M, Norwegian Sea, during the 1997 spring bloom: feeding of adult female Calanus finmarchicus. Mar Ecol Prog Ser 172:127-137

Irigoien $\mathrm{X}$, Harris RP, Verheye HM, Joly $\mathrm{P}$ and 14 others (2002) Copepod hatching success in marine ecosystems with high diatom concentrations. Nature 419:387-389

Jossi JW, Kane J (2000) An atlas of seasonal mean abundances of the common zooplankton of the United States northeast continental shelf ecosystem. Bull Sea Fish Inst 3: $1-21$

Kane J (1993) Variability of zooplankton biomass and dominant species abundance on Georges Bank, 1977-1986. Fish Bull 91:464-474

Lynch DR, Gentleman WC, McGillicuddy DJ, Davis CS (1998) Biological/physical simulations of Calanus finmarchicus population dynamics in the Gulf of Maine. Mar Ecol Prog Ser 169:189-210

Marcus NH (1996) Ecological and evolutionary significance of resting eggs in marine copepods: past, present, and future studies. Hydrobiologia 320:141-152

McGillicuddy DJ, Lynch DR, Moore AM, Gentleman WC, Davis CS, Meise CJ (1998) An adjoint data assimilation approach to diagnosis of physical and biological controls on Pseudocalanus spp. in the Gulf of Maine-Georges Bank region. Fish Oceanogr 7:205-218

McLaren IA, Laberge E, Corkett CJ, Sévigny JM (1989a) Life cycles of four species of Pseudocalanus in Nova Scotia. Can J Zool 67:552-558

McLaren IA, Tremblay MJ, Corkett CJ, Roff JC (1989b) Copepod production on the Scotian Shelf based on life-history analyses and laboratory rearings. Can J Fish Aquat Sci 46: 560-583

Meise CJ, O'Reilly JE (1996) Spatial and seasonal patterns in abundance and age-composition of Calanus finmarchicus in the Gulf of Maine and on Georges Bank: 1977-1987. Deep-Sea Res II 43:1473-1501

Meise-Munns CJ, Green J, Ingham M, Mountain D (1990) Interannual variability in the copepod populations of Georges Bank and the western Gulf of Maine. Mar Ecol Prog Ser 65:225-232

Melle W, Skjoldal HR (1998) Reproduction and development of Calanus finmarchicus, C. glacialis and C. hyperboreus in the Barents Sea. Mar Ecol Prog Ser 169:211-228

Miller CB, Lynch DR, Carlotti F, Gentleman WC, Lewis CVW 
(1998) Coupling of an individual-based population dynamic model of Calanus finmarchicus to a circulation model for the Georges Bank region. Fish Oceanogr 7: $219-234$

Mountain DG, Strout GA, Beardsley RC (1996) Surface heat flux in the Gulf of Maine. Deep-Sea Res II 43:1533-1546

Niehoff B, Hirche HJ (1996) Oogenesis and gonad maturation in the copepod Calanus finmarchicus and the prediction of egg production from preserved samples. Polar Biol 16: 601-612

Niehoff B (2003) Gonad morphology and oocyte maturation in Pseudocalanus spp. in relation to spawning activity. Mar Biol (in press)

Niehoff B, Klenke U, Hirche HJ, Irigoien X, Head R, Harris R (1999) A high frequency time series at Weathership $M$, Norwegian Sea, during the 1997 spring bloom: the reproductive biology of Calanus finmarchicus. Mar Ecol Prog Ser 176:81-91

Ohman MD, Hirche HJ (2001) Density-dependent mortality in an oceanic copepod population. Nature 412:638-641

Ohman MD, Runge JA (1994) Sustained fecundity when phytoplankton resources are in short supply: omnivory by Calanus finmarchicus in the Gulf of St. Lawrence. Limnol Oceanogr 39:21-36

Ohman MD, Runge JA, Durbin EG, Field DB, Niehoff B (2002) On birth and death in the sea. Hydrobiologia 480:55-68

O'Reilly JE, Zetlin C (1998) Seasonal, horizontal, and vertical distribution of phytoplankton chlorophyll $a$ in the northeast U.S. continental shelf ecosystem. NOAA Tech Rep NMFS 139, Wash., DC

Parsons TR, Maita Y, Lalli CM (1984) A manual of chemical and biological methods for seawater analysis. Pergamon Press, New York

Perry RI, Hurley PCF, Smith PC, Koslow JA, Fournier RO (1989) Modelling the initiation of spring phytoplankton blooms: a synthesis of physical and biological interannual variability of southest Nova Scotia, 1983-85. Can J Fish Aquat Sci 46(Suppl 1):183-199

Perry RI, Harding GC, Loder JW, Tremblay MJ, Sinclair MM, Drinkwater KF (1993) Zooplankton distributions at the Georges Bank front system: retention or dispersion? Cont Shelf Res 13:357-383

Pingree RD, Holligan PM, Mardell GT, Head RN (1976) The influence of physical stability on spring, summer and autumn phytoplankton blooms in the Celtic Sea. J Mar Biol Assoc UK 56:845-873

Plourde S, Runge JA (1993) Reproduction of the planktonic copepod Calanus finmarchicus in the Lower St. Lawrence Estuary: relation to the cycle of phytoplankton production

Editorial responsibility: Kenneth Sherman (Contributing Editor), Narragansett, Rhode Island, USA and evidence for a Calanus pump. Mar Ecol Prog Ser 102: $217-227$

Richardson K, Jonasdottir SH, Hay SJ, Christoffersen A (1999) Calanus finmarchicus egg production and food availability in the Faroe-Shetland Channel and northern North Sea: October-March. Fish Oceanogr 8(Suppl):153-162

Riley GA (1957) Phytoplankton of the North Central Sargasso Sea, 1950-52. Limnol Oceanogr 2:252-270

Roe HSJ, Angel MV, Badcock J, Domanski P, James P, Pugh PR, Thurston MH (1984) The diel migrations and distributions within a mesopelagic community in the North East Atlantic. 1. Introduction and sampling procedures. Prog Oceanog 13:245-260

Runge JA, Roff JC (2000) The measurement of growth and reproductive rates. In : Harria R, Wiebe P, Lenz J, Skoldal HR, Huntley $M$ (eds) ICES zooplankton methodology manual. Academic Press, London, p 401-454

Saiz E, Calbet A, Fara A, Berdalet E (1998) RNA content of copepods as a tool for determining adult growth rates in the field. Limnol Oceanogr 43:465-470

Sherman K, Green JR, Goulet JR, Ejsymont L (1983) Coherence in zooplankton of a large northwest Atlantic ecosystem. Fish Bull 81:855-862

Smith PC (1983) The mean and seasonal circulation off southwest Nova Scotia. J Phys Oceanogr 13:1034-1054

Sverdrup HU (1953) On conditions for the vernal blooming of phytoplankton. J Cons Int Explor Mer 18:287-295

Townsend DW, Spinrad RW (1986) Early spring phytoplankton blooms in the Gulf of Maine. Cont Shelf Res 6:515-529

Townsend DW, Keller MD, Sieracki ME, Ackleson SG (1992) Spring phytoplankton blooms in the absence of vertical water column stratification. Nature 360:59-62

Tremblay MJ, Roff JC (1983) Community gradients in the Scotian Shelf zooplankton. Can J Fish Aquat Sci 40: $598-611$

Wagner M (2000) Nucleic acids as indicators of growth rates and nutritional condition of the copepod Calanus finmarchicus (Copepoda: Calanoida). PhD thesis, University of Rhode Island, Kingston, RI

Wagner M, Durbin EG, Buckley L (1998) RNA:DNA ratios as indicators of nutritional condition in the copepod Calanus finmarchicus. Mar Ecol Prog Ser 162:173-181

Wagner M, Campbell RG, Boudreau CA, Durbin EG (2001) Nucleic acids and growth of Calanus finmarchicus in the laboratory under different growth and temperature conditions. Mar Ecol Prog Ser 221:185-197

Whitledge TE, Veidt DM, Mallow SC, Patton CJ, Wirick CD (1986) Automated nutrient analyses in seawater. Publication BNL 38990. Brookhaven National Laboratory, Upton

Submitted: July 18, 2002; Accepted: January 21, 2003

Proofs received from author(s): May 5, 2003 